\begin{tabular}{|c|c|c|}
\hline BENTHAM OPEN & $\begin{array}{c}\text { The Open Chemical Engineering } \\
\text { Journal }\end{array}$ & $\begin{array}{l}\text { The Ooen } \\
\text { Chemical Engineering } \\
\text { lournal }\end{array}$ \\
\hline CrossMark & $\begin{array}{l}\text { Content list available at: www.benthamopen.com/TOCENGJ/ } \\
\text { DOI: } 10.2174 / 1874123101812010036\end{array}$ & 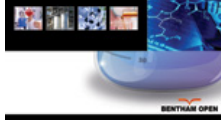 \\
\hline
\end{tabular}

RESEARCH ARTICLE

\title{
Chemical Kinetics of Alkaline Pretreatment of Napier Grass (Pennisetum purpureum) Prior Enzymatic Hydrolysis
}

Samuel Eshorame Sanni*, Olasubomi Akinrinola, Esther Ojima Yusuf, Omololu Oluwatobi Fagbiele and Oluranti Agboola

Department of Chemical Engineering, Covenant University, P.M.B. 1023, Ota, Ogun State, Nigeria

Received: December 27, 2017

Revised: January 31, 2018

Accepted: April 8, 2018

\section{Abstract:}

Background:

Napier grass is a naturally abundant waste material that can be cultivated over a vast area of land which makes it a viable source for sugar and bioethanol production.

\section{Introduction:}

The presence of lignin in the biomass makes cellulose inaccessible for conversion to useful products, however, in order to provide for efficient utilization of the waste material, reagent and energy, a study on the kinetics of lignin removal from Napier grass was carried out in this work using 1 and $3 \mathrm{w} / \mathrm{w} \% \mathrm{NaOH}$ at temperatures between 80 and $120^{\circ} \mathrm{C}$.

\section{Materials \& Methods:}

Based on the investigation, there was increased lignin removal for increased $\mathrm{NaOH}$ concentration. Kinetic parameters were also determined and it was observed that, the reaction of lignin in Napier grass with $\mathrm{NaOH}$ obeys a pseudo-zero or pseudo-fractional order kinetics. Furthermore, the orders of the reaction for the pretreatment conditions of $3 \mathrm{w} / \mathrm{w} \% \mathrm{NaOH}$ at $100^{\circ} \mathrm{C}$ and those of 3 and $1 \mathrm{w} / \mathrm{w} \mathrm{NaOH}$ at $120^{\circ} \mathrm{C}$ gave close reaction orders of $0.2,0.22$ and 0.24 respectively after 110 minutes, which implies that, for the three cases, the residual lignin in the extract was almost the same at the pretreatment conditions while slight differences are evident in their pseudo rate constants. Also, it was observed that, the activation energy of the reaction reduced significantly as the concentration of $\mathrm{NaOH}$ increased from $1 \mathrm{w} / \mathrm{w}-3 \mathrm{w} / \mathrm{w} \%$.

\section{Conclusion:}

Based on the AIL and the total lignin (i.e. AIL + ASL) in the Napier grass, the recorded delignification efficiencies at the optimum pretreatment time of $17.5 \mathrm{~h}$ are 90 and $76 \%$ respectively. In addition, the adopted Differential Technique (DT) combined with the Ostwald Method of Isolation (OMI) can be accurately used to study the kinetics of lignin removal from Napier grass.

Keywords: Alkaline Pretreatment, Chemical Kinetics, Delignification, Napier Grass, Pseudo-fractional Order, Ostwald Method of Isolation.

\section{INTRODUCTION}

Since the Vietnam war, energy availability has become increasingly critical [1]. Potential sources of fuel energy include solar, wind, geothermal, nuclear and other forms of renewable energy. First-generation biofuels are produced from food crops such as sugar cane and corn [2]. However, food competition led to the emergence of second-generation biofuels which are sourced from non-food feedstock and agricultural wastes while third-generation biofuels find their

* Address correspondence to this author at the Department of Chemical Engineering, Covenant University, P.M.B. 1023, Ota, Ogun State, Nigeria, Tel: +234 8034332497; E-mail: adexz3000@yahoo.com 
origin in synthetic fibres [3]. Fossil fuels used to be the most abundant energy sources but their continuous depletion have given rise to adverse environmental effects. According to recent works, waste materials are being exploited as very good sources of energy. Amongst the available waste materials, Napier grass (Pennisetum purpureum) was selected for this research because of its high productivity per hectare, low cost, its adaptability to infertile land and the usefulness of the whole plant [4]. Napier grass can be converted to sugar or ethanol. In the production of bioethanol from cellulose, the cellulose is first separated from lignin and hemicellulose by pretreatment methods. The purpose of the pretreatment is to provide easy enzyme-accessibility of carbohydrate polymers [5], remove lignin, reduce cellulose crystallinity, increase the porosity of the materials, improve substrate ability to form sugars and prevent loss of carbohydrate and the formation of byproducts which are inhibitory to hydrolysis and fermentation processes. Some bases/alkalis can also be used for pretreatment of lignocellulosic materials and the effect of alkaline pre-treatment depends on the lignin content of the materials [6]. Amongst the pretreatment technologies, alkaline pretreatment has received much attention because it is less energy intensive and relatively inexpensive [7]. After pretreatment, the substrate is then hydrolyzed using chemicals/enzymes. Enzymes are very active on cellulose because they both have a similar chemical structure. Using acid as substitute for enzymes is not appropriate for hydrolysis because of the high temperature requirement and the issue of acid corrosion, whereas the use of enzymes guarantee higher specificity and more neutral reaction without the formation of byproducts $[4,8]$. However, pretreatment/delignification kinetics may be used to optimize the production of high value sugars or maximize utilization of feed stocks nutrients. Besides providing access route to the cellulose in biomass, initial pretreatment of biomass and enzymatic hydrolysis lead to the recovery of residual lignin which can be converted to p-hydroxy-phenyl propane by taking advantage of the structural adjustments in the lignin matrix on further pretreatment $[8,9]$. In a similar work, it was asserted that depolymerization and condensation reactions are the mechanisms responsible for lignin removal during biomass pretreatment [10]. Based on literature, the mechanisms for lignin removal from plant biomass bring about size reduction of the substrate, physical redistribution of the components, depolymerization and solubilization [11]. Shea-tree sawdust delignification kinetics has been investigated [12]. The raw material was pretreated at $120-150^{\circ} \mathrm{C}$. Based on their results, they concluded that the peroxide pretreatment adopted for lignin removal improved the biofuel yield.

In a recent study, the kinetics of lignin removal from corn Stover was carried out by soaking the biomass in different concentrations of aqueous ammonia aided by thermal treatment between 30 and $70^{\circ} \mathrm{C}$ [13]. Also, the pretreatment of corn Stover was conducted at temperatures of $170-230^{\circ} \mathrm{C}$ and $150-210^{\circ} \mathrm{C}$ using hot water and dilute acid to remove lignin from the substrate and it was discovered that pretreatment conditions from $200-230^{\circ} \mathrm{C}$ did not enhance lignin removal from the biomass [14]. The comparative kinetics of sodium-chlorite acetic acid and peracetic acid delignification of four biomass samples (switch grass, pine saw dust, poplar and corn Stover) was studied [15] with a record of $>90 \%$ delignification efficiency, however, they added that, the choice of pretreatment for biomass delignification is substrate dependent; similar works were carried out using acid and alkali pretreatments for poplar and switch grass [16] and oat hull biomass [17]. It has been reported that delignification enhances sugar yields as high as over $90 \%$ for biomasses such as woods, grasses and corn [18]. They also discussed the advantages of several pretreatment technologies prior hydrolysis and fermentation. The structural modifications of lignin occurring in the stages of maturity of Napier grass have been discussed [19]. The physicochemical changes occurring in lignocellulosic biomasses during pretreatment can be determined experimentally, which will aid the development of models for accurate design of pretreatment processes [20]. Modelling and optimization of Napier grass pretreatment using four combined pretreatment techniques for glucose and xylose production was carried out [21], where they reported lower sugar yield from $\mathrm{NaOH}$ and moist heat, and $\mathrm{NaOH}$ and microwave hybridized pretreatment methods as compared to the HCl-hybridized forms of pretreatments; two reasons may have been responsible for the lower sugar yield and these include, the interference of thermal radiation with the action of $\mathrm{NaOH}$ in the sample and the selectivity of the lignin matrix for $\mathrm{NaOH}$. Lignin binds to sites within a biomass/substrate especially at areas where it is least desired for industrial applications [22 - 27].

Therefore, the objective of this study is to investigate the alkaline pretreatment kinetics of lignin removal in Napier grass under different pretreatment conditions using the differential rate law and the method of isolation because previous works on Napier grass pretreatment have not exploited the application of these methods in determining the kinetic parameters. Also, first-order kinetics is usually assumed for wood as biomass substrate which may not necessarily suffice for other biomasses.

\section{MATERIALS, REAGENTS AND EQUIPMENT}

40-day old Napier grass (Pennisetum purpureum) was harvested from Covenant University surrounding, in Ota, 
Ogun state. It was separated from impurities (plants, leaves, sand, stones and dirt). The separated Napier grass was washed and air dried for 7 days. It was then milled and sieved using a 500 micron-sieve. After which the milled grass was stored in sealed plastic bags at room temperature for characterization and pretreatment. The following reagents were used for pretreatment and hydrolysis: $\mathrm{NaOH}$ of $99.8 \%$ made by Fischer chemical, $\mathrm{H}_{2} \mathrm{SO}_{4}$ of $97 \%$ purity made by Sigma Aldrich, Absolute ethanol of $99.9 \%$ purity-analytical grade by Fischer chemical, $\mathrm{CaCO}_{3}$ of $99 \%$ purity by Nikitia Minchem Industries, Distilled water, Sodium citrate buffer ( $\mathrm{pH} 4.8$ ), Dinitrosalisilic acid reagent (DNSA reagent).

UV mass spectrophotometer: 7310 visible Scanning Spectrophotometer fitted with 10 x $10 \mathrm{~mm}$ cuvette holder, 320 $1000 \mathrm{~nm}$ wavelength, resolution $=1 \mathrm{~nm}$ accuracy of $\pm n m$, manufactured by Jenway, Oven Vs-1202d3 by Vision Scientific Ltd., electronic weighing balance manufactured by Swastic Systems \& Services, India, measuring cylinder, flat bottom flasks, conical flask and beakers manufactured by J Sill Borosilicates, filter paper by Whatman No. 2V and of $18 \mathrm{~cm}$ diameter.

\section{EXPERIMENTAL PROCEDURE}

\subsection{Characterization of Napier grass (Pennisetum purpureum)}

Napier grass (Pennisetum purpureum) was characterized prior and after alkaline pretreatment to determine the total percentage of cellulose, hemicellulose, lignin, extractives, moisture and ash in the biomass. Structural carbohydrates and lignin in the grass were determined based on National Renewable Energy Laboratory (NREL) procedures [14, 28]. The percent extractives, moisture and ash were determined based on the American Society of Testing and Material standards as used by Dussadee et al. [29].

\subsubsection{Determination of Moisture Content}

$5 \mathrm{~g}$ Napier grass was weighed and put on cellulose paper of known weight. This was done with the aid of the weighing balance. The sample was placed in a crucible and transferred to an oven at $105^{\circ} \mathrm{C}$. After $1 \mathrm{~h}$, the sample was allowed to cool in the desiccator for 15 mins. The weight of the sample was taken and recorded. The sample was further dried by putting it in the oven for another $3 \mathrm{~h}$ at 30 minutes interval at $105^{\circ} \mathrm{C}$ until a constant weight was achieved. The samples were removed and allowed to cool in the desiccator for $15 \mathrm{mins}$. The total dry solids weight and the \%moisture of the sample were determined using equations (1) and (2) respectively.

$$
\begin{gathered}
\% \text { total solids }=\left(\frac{\text { weight }_{\text {driedaamp }+ \text { dish }}-\text { weight }_{\text {dish }}}{\text { weight }_{\text {samplerecived }}}\right) * 100 \% \\
\% \text { moisture }=1-\left(\frac{\text { weight }_{\text {driedaamp }+ \text { dish }}-\text { weight }_{\text {dish }}}{\text { weight }_{\text {samplerecived }}}\right) * 100 \%
\end{gathered}
$$

\subsubsection{Determination of Extractives}

$5 \mathrm{~g}$ of Napier grass biomass was weighed and poured onto a cellulose paper of known weight which was folded to take the shape of the thimble of the Soxhlet extractor. The paper and its content were then placed in the thimble of the Soxhlet extractor. With the aid of a volumetric flask, $190 \mathrm{ml}$ of ethanol was measured and transferred into the round bottom flask.

The Soxhlet extractor was then mounted on the heating mantle for 8 hours for extraction to take place. After extraction, the sample was air dried for 24 hours and put in the oven set at $105^{\circ} \mathrm{C}$ until constant weight was achieved; the ordinary dry weight of the sample was then determined using equation (3). The solvent containing the extractives was now heated to evaporate, in order to leave the extractives as residue. The weight of the round bottom flask plus the extractives was then determined and recorded. The \%extractives was then obtained from equation (4).

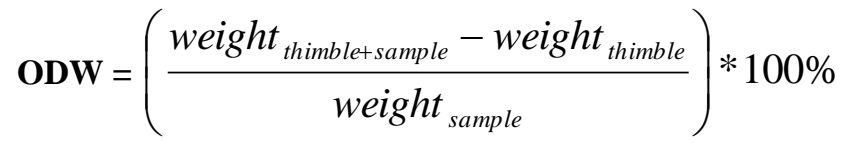

$$
\begin{aligned}
& \% \text { extractives }=\left(\frac{\text { weight }_{\text {flask+extractives }}-\text { weight }_{\text {flask }}}{\text { weight }_{\text {ODWsample }}}\right) * 100 \%
\end{aligned}
$$




\subsubsection{Estimation of \%hemicellulose}

A standard solution of $0.5 \mathrm{M} \mathrm{NaOH}$ was produced with distilled water. $1 \mathrm{~g}$ of the extractive free Napier grass sample was weighed and kept inside a $250 \mathrm{ml}$ Erlenmeyer flask. With the aid of volumetric flask, $150 \mathrm{ml}$ of $\mathrm{NaOH}$ was weighed and poured into the flask containing $1 \mathrm{~g}$ of the sample. The Erlenmeyer flask was placed inside the oven whose temperature was adjusted to $100^{\circ} \mathrm{C}$. The sample was then allowed to boil for $4 \mathrm{~h}$. After heating and the reaction time elapsed, the sample was brought out of the oven and allowed to cool to room temperature. Then the sample was filtered via Buchner funnel vacuum filtration set up and a pump; cellulose filter paper was also used to carry out the filteration. The sample residue was then washed with distilled water until the $\mathrm{pH}$ of the filterate was 7 in order to ensure that all the $\mathrm{NaOH}$ in the sample had been removed. The sample was dried in the oven at temperature of $105^{\circ} \mathrm{C}$ to a constant weight. Thereafter, the sample was then allowed to cool in the dessicator with the dry weight of the sample measured using a weighing balance. The Hemicellulose content of the Napier grass was then obtained using equation (5).

$$
\% \text { hemicellulose }=\left(\frac{\text { weight } t_{\text {reference }}-\text { weight }}{\text { weight } t_{\text {reference }}}\right) * 100 \%
$$

\subsubsection{Determination of Lignin and Ash Content Procedure}

Two types of lignin were accounted for:

\subsubsection{Insoluble Lignin}

$300 \mathrm{mg}$ of extractive free sample was weighed and put inside a test tube. $3 \mathrm{ml}$ of $72 \mathrm{w} / \mathrm{w} \% \mathrm{H}_{2} \mathrm{SO}_{4}$ was measured and added to the sample for complete hydrolysis of the cellulose and hemicellulose. The test tube was swirled gently to allow for complete mixing and access of the sulfuric acid to the whole material. The sample was then kept at room temperature for $2 \mathrm{~h}$ while shaking at 30 mins interval to allow for complete hydrolysis. The sample was transferred carefully to a $250 \mathrm{ml}$ Erlenmeyer flask and $84 \mathrm{ml}$ of distilled water was added. The sample was autoclaved for $1 \mathrm{~h}$ at $121^{\circ} \mathrm{C}$ and then cooled to room temperature. The sample was filtered with the aid of the filtering crucible and filter paper. Then the residue was dried at $105^{\circ} \mathrm{C}$ in an oven till constant weight then the insoluble residue weight was recorded and using equation (3), the Ordinary Dry Weight (ODW) of the Sample was calculated. The residue was poured into a crucible and the total weight of crucible and sample was recorded. The crucible + sample was then put in the furnace for $6 \mathrm{~h}$ at $575^{\circ} \mathrm{C}$ to obtain the ash content. The ash content was subtracted from the total amount of insoluble residue to obtain the quantity of insoluble lignin using equation (6).

\subsubsection{Soluble Lignin}

$3 \mathrm{ml}$ of the filtrate obtained in section 3.1.4.1 was taken to the UV-Spectrometer to determine the absorbance of the sample at a wavelength of $240 \mathrm{~nm}$. The Acid Insoluble and Acid Soluble Lignin were obtained from equations (7) and (8) respectively.

$$
\begin{aligned}
& \% \text { acid insoluble residue }(\mathbf{A I R})=\left(\frac{\text { weight }_{\text {crucible }+ \text { AIR }}-\text { weight }_{\text {crucible }}}{\text { weight }_{\text {ODWsample }}}\right) * 100 \% \\
& \% \mathbf{A I L}=\left(\frac{\left(\text { weight }_{\text {crucible }+ \text { AIR }}-\text { weight }_{\text {crucible }}\right)-\left(\text { weight }_{\text {crucible }+ \text { ash }}-\text { weight }_{\text {crucible }}\right)}{\text { weight }}\right) * 100 \% \\
& \% \mathbf{A S L}=\left(\frac{\left(U V_{\text {abs }} * \text { Volume }_{\text {filtrate }} *\right. \text { Dilution }}{\text { weight }_{\text {ODWsample }} * \varepsilon * \text { wavelength }_{\text {absorption }}}\right) * 100 \%
\end{aligned}
$$

The modified Beer Lambert's equation:

$$
\begin{gathered}
\mathrm{A}=\varepsilon * \mathrm{C} * \lambda \\
\mathrm{C}=(\mathrm{A} * \mathrm{D}) /(\varepsilon * \lambda)
\end{gathered}
$$


Where:
$\mathrm{A}=$ absorbance at $240 \mathrm{~nm}$
$\mathrm{D}=$ dilution factor
$\lambda=$ absorption wavelength
$\varepsilon=$ absorptivity and $\mathrm{C}=$ lignin concentration in $\mathrm{NaOH}$

\subsubsection{Determination of Cellulose Content}

Considering the amount of hemicellulose, ash, ASL, AIL, and extractives estimated, the \%cellulose in the Napier grass sample was then determined using equation (11).

$$
\% \text { Cellulose }=100-\% \text { Hemicellulose }-\% \text { Lignin }(\text { AIL }+ \text { ASL })-\% \text { Ash }-\% \text { Extractives }
$$

\subsection{Alkaline Pretreatment of Napier Grass (Pennisetum purpureum)}

$1 \mathrm{~g}$ of Napier grass was treated in a $250 \mathrm{~mL}$ Erlenmeyer flask with 1 and $3 \mathrm{w} / \mathrm{v}$ separate solutions of $50 \mathrm{~mL} \mathrm{NaOH}$ between $80-120^{\circ} \mathrm{C}$ at a temperature interval of $10^{\circ} \mathrm{C}$ and time interval of 30 minutes for a total of 45 runs using Table 1. The samples were withdrawn, filtered and analyzed using a UV spectrophotometer. The flask was covered with aluminum foil and placed in the oven. Alkaline method of pretreatment was selected because alkaline pretreatment can take place at temperatures as low as $45-50^{\circ} \mathrm{C}$ and pressure of $1 \mathrm{~atm}$ compared to other pretreatment methods [30]. Also, in terms of reactivity, alkaline pretreatment is safer relative to acid pretreatment because of the tendency of side reactions. Alkalis are relatively cheap and can be recovered by carbonating with $\mathrm{CO}_{2}$ [31].

Table 1. Absorbance and concentration of lignin in filtrate for $1 \mathrm{w} / \mathrm{w} \% \mathrm{NaOH}$ pretreatment.

\begin{tabular}{|c|c|c|c|c|c|c|c|c|c|c|}
\hline $\mathbf{t}, \min$ & $\begin{array}{c}\text { Abs. } \\
\text { at } \\
80^{\circ} \mathrm{C}\end{array}$ & $\begin{array}{c}\text { Conc. } \\
\text { at } \\
80^{\circ} \mathrm{C}\end{array}$ & $\begin{array}{l}\text { Abs. } \\
\text { at } \\
90^{\circ} \mathrm{C}\end{array}$ & $\begin{array}{l}\text { Conc. } \\
\text { at } \\
90^{\circ} \mathrm{C}\end{array}$ & $\begin{array}{c}\text { Abs. } \\
\text { at } \\
100^{\circ} \mathrm{C}\end{array}$ & $\begin{array}{c}\text { Conc. } \\
\text { at } \\
100^{\circ} \mathrm{C}\end{array}$ & $\begin{array}{c}\text { Abs. } \\
\text { at } \\
110^{\circ} \mathrm{C}\end{array}$ & $\begin{array}{c}\text { Conc. } \\
\text { at } \\
110^{\circ} \mathrm{C}\end{array}$ & $\begin{array}{c}\text { Abs. } \\
\text { at } \\
120^{\circ} \mathrm{C}\end{array}$ & $\begin{array}{c}\text { Conc. } \\
\text { at } \\
120^{\circ} \mathrm{C}\end{array}$ \\
\hline 0 & 0 & 0 & 0 & 0 & 0 & 0 & 0 & 0 & 0 & 0 \\
\hline 30 & 0.14 & 0.28 & 0.24 & 0.49 & 0.30 & 0.61 & 0.41 & 0.81 & 0.75 & 1.50 \\
\hline 60 & 0.26 & 0.53 & 0.55 & 1.09 & 0.73 & 1.46 & 1.10 & 2.2 & 1.49 & 2.99 \\
\hline 90 & 0.56 & 1.12 & 0.97 & 1.94 & 1.32 & 2.64 & 2.44 & 4.88 & 2.53 & 5.07 \\
\hline
\end{tabular}

\subsection{Determination of kinetic parameters}

\subsubsection{Determination of Reaction Orders with respect to $\mathrm{NaOH}$}

Given the reaction between Lignin (A) and $\mathrm{NaOH}$ (B) to give product (C) is represented by the following stoichiometric relationship as given in equation (12):

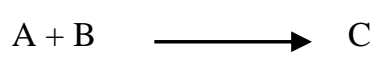

Rate of disappearance of $\mathrm{A}$ is given as:

$$
-r_{A}=\frac{-\partial C_{A}}{\partial t}=k C_{A}^{\alpha} C_{B}{ }^{\beta}
$$

Assuming $\mathrm{NaOH}$ is in excess relative to the volume of A (lignin), the method of isolation then applies thus;

$$
\begin{gathered}
-r_{A}=\frac{-\partial C_{A}}{\partial t}=\left(k C_{B O}{ }^{\beta}\right) C_{A}^{\alpha} \\
\text { If } k^{*}=k C_{B O}{ }^{\beta}
\end{gathered}
$$

Therefore, from 


$$
-r_{A}=\frac{-\partial C_{A}}{\partial t}=k^{*} C_{A}^{\alpha}
$$

Linearizing equation (16) gives:

$$
\ln \left(-r_{A}\right)=\ln \frac{\partial C_{A}}{\partial t}=\ln k^{*}+\alpha \ln C_{A}
$$

Where:

$-r_{A}=d C_{A} / d t=$ the rate of disappearance of lignin from Napier grass

$C_{A}=$ concentration of residual lignin in the biomass

$k^{*}=$ pseudo rate constant or pseudo velocity constant for the reaction

$k=$ true rate constant or true velocity constant for the reaction

$\alpha=$ the order of the reaction with respect to lignin

$\beta=$ the order of the reaction with respect to $\mathrm{NaOH}$

From equation (17), a plot of $\ln \left(-\mathrm{r}_{\mathrm{A}}\right)$ vs $\ln \mathrm{C}_{\mathrm{A}}$ gives $\alpha$ as the slope and $\ln \mathrm{k}^{*}$ as intercept

In order to obtain the true rate constant of the reaction, the order of reaction with respect to $\mathrm{NaOH}(\mathrm{B})$ and the overall order of the reaction, several initial concentrations of $\mathrm{NaOH}$ can be used by repeating the experiments in section 3.2 having determined the pseudo rate constant and order of the reaction with respect to lignin. The varied initial concentrations of $\mathrm{NaOH}$ will then be measured experimentally alongside their corresponding pseudo rate constants. Afterwards, the natural log of equation (15) is taken which informs that, a plot of the pseudo rate constant against the initial $\mathrm{NaOH}$ concentration will give $\beta$ as the reaction order with respect to $\mathrm{NaOH}$ with $\ln \mathrm{k}$ as the intercept. In addition, the natural log inverse of the intercept can then be obtained which gives the value of the true rate constant for the reaction.

However, since the true rate constants variation are difficult to determine for varied concentrations of $\mathrm{NaOH}$, the pseudo rate constants for the reaction were used to estimate the activation energies for the reactions at the different conditions.

\subsubsection{Determination of Activation Energy for the Reaction between $\mathrm{NaOH}$ and Lignin in Napier Grass}

From the Arrhenius Equation:

$$
k=k_{o} e^{-E_{A} / R T}
$$

Where:

$k=$ rate constant at a specified temperature (used as pseudo rate constant)

$k_{o}=$ the pre-exponential factor

$E_{A}=$ activation energy of the reaction between $\mathrm{NaOH}$ and lignin

$T=$ the reaction temperature

$e=$ inverse of natural $\log$

$R=$ gas constant $(8.314 \mathrm{~J} / \mathrm{mol} . \mathrm{K})$

Taking the natural log of equation (18) gives:

$$
\ln k=\ln k_{o}-\frac{E_{A}}{R T}
$$




\subsubsection{Determination of Optimum Pretreatment Time}

For the pretreatment temperatures considered, the time of pretreatment was extended for the pretreatment temperature that gave the highest amount of lignin in the extract $/ \mathrm{NaOH}$. This was done in order to conserve energy and resources with a view of staying within the best pretreatment conditions that are mostly recommended for biomass pretreatment. The results obtained by varying pretreatment time and obtaining the corresponding absorbance alongside the concentrations of lignin in the extract of the sample at $240 \mathrm{~nm}$ is as shown in Table 2.

\section{RESULTS AND DISCUSSION}

The results from Napier grass compositional analysis is given in Fig. (1).

\subsection{Compositional Analysis}

Considering Fig. (1), the Napier grass consists mainly of cellulose, hemicellulose, Acid Insoluble Lignin (AIL), extractives, moisture, ash, Acid Soluble Lignin (ASL).

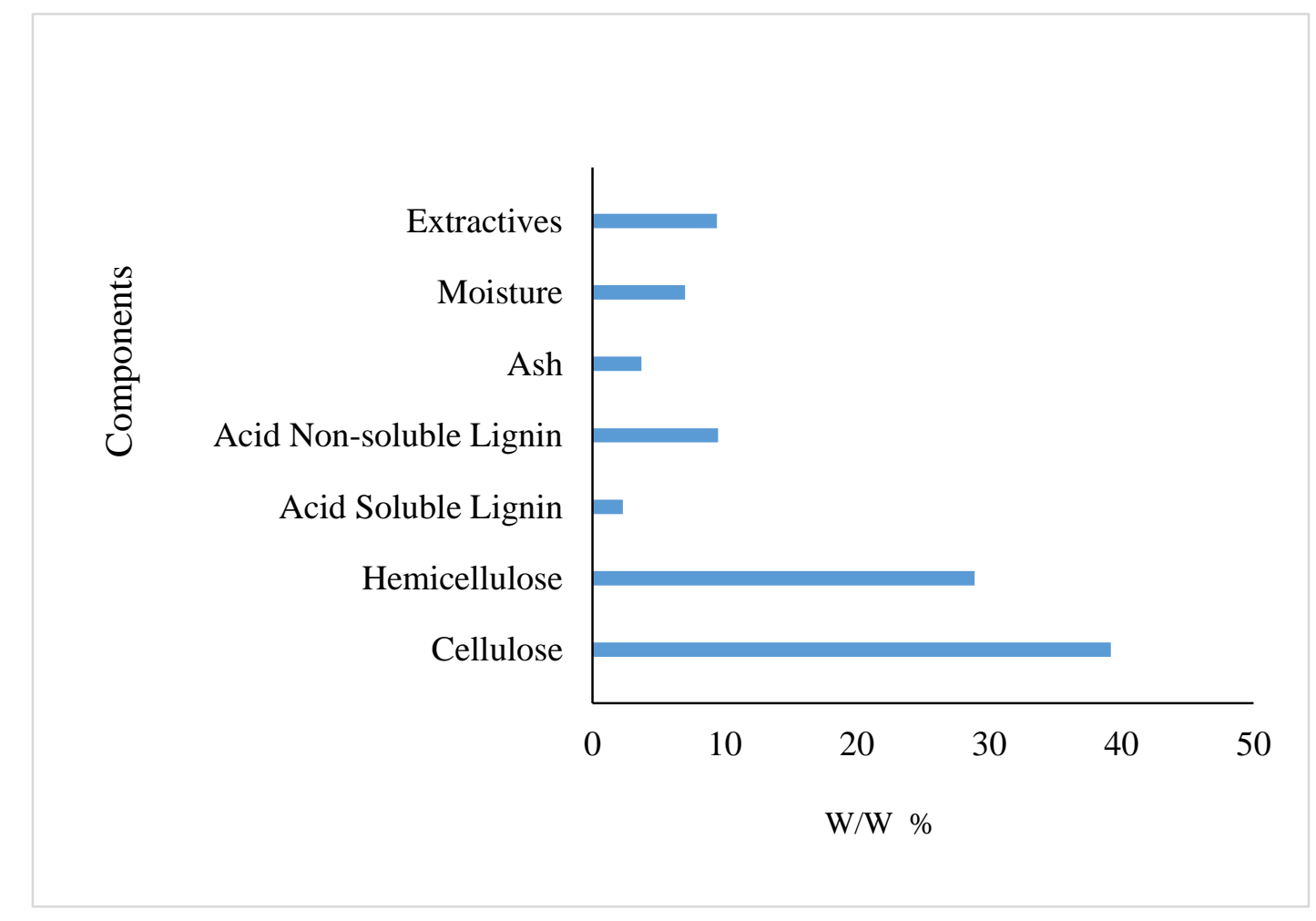

Fig. (1). Percent Composition of the Napier grass.

\subsection{Calibration Graph}

The concentration of lignin in $\mathrm{NaOH}$ after each pretreatment condition was determined by UV-visible spectrophotometer which was used to read the absorbance at a wavelength of $240 \mathrm{~nm}$ and then the modified BeerLambarts equation was used to calculate the lignin concentration with a molar absorptivity coefficient value of 25 $\mathrm{L}(\mathrm{gcm})^{-1}$.

\subsubsection{Effect of Temperature and Time of Pretreatment}

At increased temperatures and pretreatment time, for $1 \mathrm{w} / \mathrm{w} \% \mathrm{NaOH}$, the absorbance increased, which is an indication of higher lignin solubility and removal from Napier grass (Table 1 and Fig. 2). Maintaining the same concentration of $\mathrm{NaOH}$ at $120^{\circ} \mathrm{C}$ gave the highest quantity of adsorbed lignin. Therefore, for effective pretreatment of 1 g Napier grass sample using $1 \mathrm{w} / \mathrm{w} \% \mathrm{NaOH}$, the best operating conditions within the limits of the pretreatment conditions applied, is heating the sample at $120^{\circ} \mathrm{C}$ for 90 mins. 


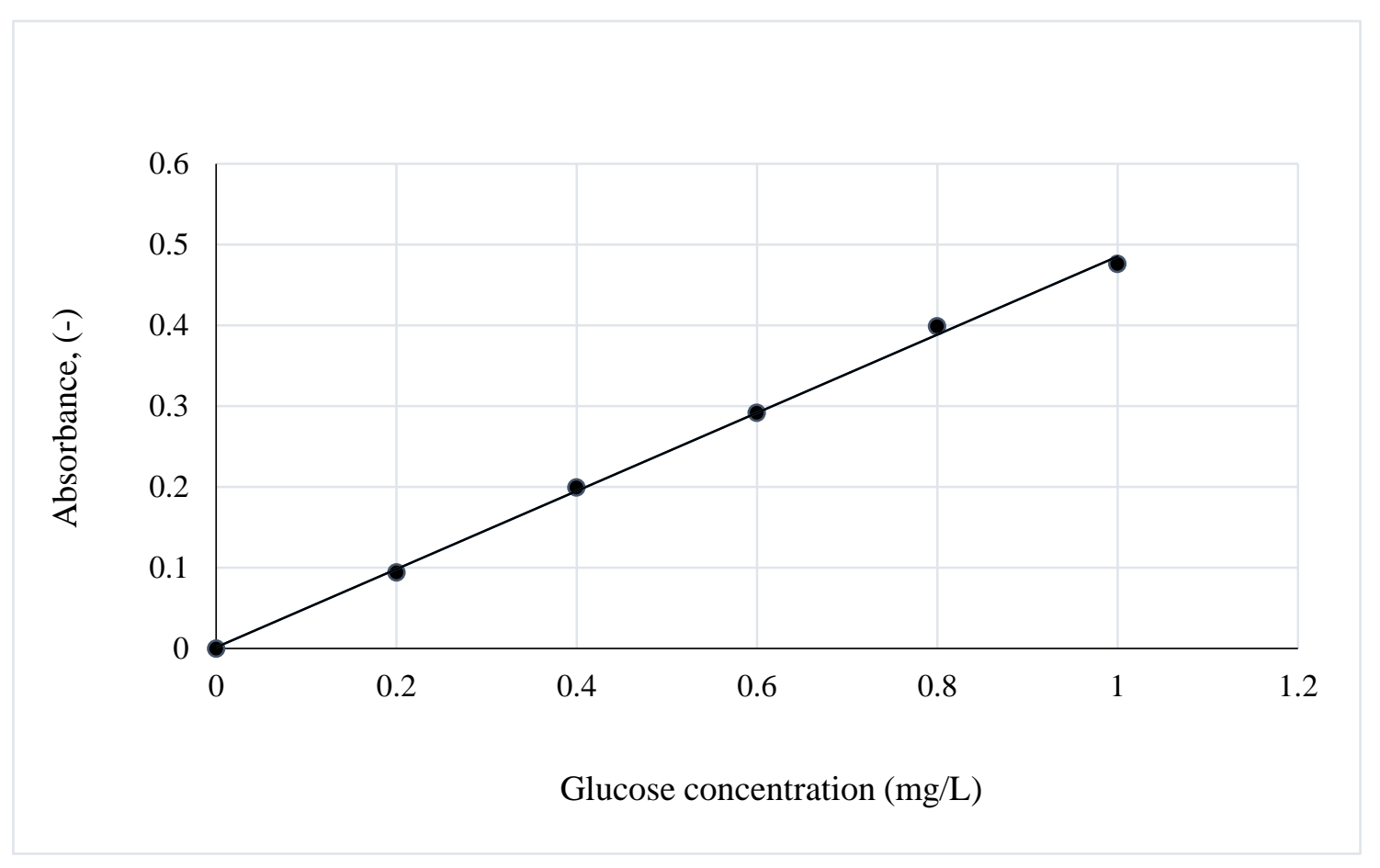

Fig. (2). Standard glucose concentration vs. absorbance.

\subsubsection{Delignification Kinetics}

The kinetic data was generated for a pretreatment time of 100 mins.

\subsubsection{Delignification Kinetics of $1 \mathrm{w} / \mathrm{w} \% \mathrm{NaOH}$}

The graphical illustration of lignin concentration variation with time is as shown in Fig. (3). The plot shows that the concentration-time graph is non-linear. Between $80-120^{\circ} \mathrm{C}$, the concentration of lignin dissolved in $\mathrm{NaOH}$ increased between 0 and 100 mins. When the pretreatment temperature was raised by $10^{\circ} \mathrm{C}$, the quantity of lignin removed (lignin in $\mathrm{NaOH}$ ) after pretreatment was $2.25 \mathrm{mg} / \mathrm{mL}$ at $90^{\circ} \mathrm{C}$ as compared to $1.4 \mathrm{mg} / \mathrm{L}$ at $80^{\circ} \mathrm{C}$, for the same pretreatment time (100 mins). From the plot, the change in concentration versus time was established in order to determine the rate of lignin removal from the sample (Table 3). Afterwards, a plot of natural log of rate versus natural log of concentration was made (Tables 4 and 5) by assuming that the reaction mixture of $\mathrm{NaOH}$ and Napier grass is homogenous so that the reactants and products are considered to be in the same phase before filtration.

Table 2. 3w/w \% $\mathrm{NaOH}$ pretreatment at $120^{\circ} \mathrm{C}$.

\begin{tabular}{|c|c|c|}
\hline Time, $\boldsymbol{\text { mins }}$ & Absorbance, - Concentration $\mathbf{~ m g} / \mathbf{m L}$ \\
\hline 0 & 0 & 0 \\
\hline 30 & 0.889 & 1.778 \\
\hline 60 & 1.689 & 3.378 \\
\hline 90 & 2.884 & 5.768 \\
\hline 120 & 3.442 & 7.351 \\
\hline 150 & 4.215 & 9.544 \\
\hline 180 & 5.611 & 13.512 \\
\hline 210 & 6.540 & 16.15 \\
\hline 240 & 7.913 & 20.041 \\
\hline 270 & 8.770 & 22.483 \\
\hline 300 & 9.782 & 26.48 \\
\hline 330 & 10.55 & 29.51 \\
\hline 360 & 11.68 & 33.95 \\
\hline 390 & 12.671 & 37.9 \\
\hline 420 & 13.961 & 43.053 \\
\hline
\end{tabular}


(Table 2) contd.....

\begin{tabular}{|c|c|c|}
\hline Time, mins & Absorbance, - & Concentration $\mathrm{mg} / \mathrm{mL}$ \\
\hline 450 & 14.882 & 45.46 \\
\hline 480 & 15.776 & 47.81 \\
\hline 510 & 16.661 & 50.15 \\
\hline 540 & 17.481 & 52.33 \\
\hline 570 & 18.983 & 56.32 \\
\hline 600 & 19.59 & 57.8 \\
\hline 630 & 20.896 & 60.96 \\
\hline 660 & 21.627 & 61.84 \\
\hline 690 & 23.145 & 63.61 \\
\hline 720 & 24.973 & 65.77 \\
\hline 750 & 26.499 & 67.57 \\
\hline 780 & 29.015 & 70.14 \\
\hline 810 & 31.76 & 72.67 \\
\hline 840 & 34.785 & 75.50 \\
\hline 870 & 38.11 & 78.59 \\
\hline 900 & 41.978 & 80.23 \\
\hline 930 & 46.501 & 82.17 \\
\hline 960 & 48.677 & 83.15 \\
\hline 990 & 52.98 & 85.07 \\
\hline 1020 & 52.979 & 85.07 \\
\hline
\end{tabular}

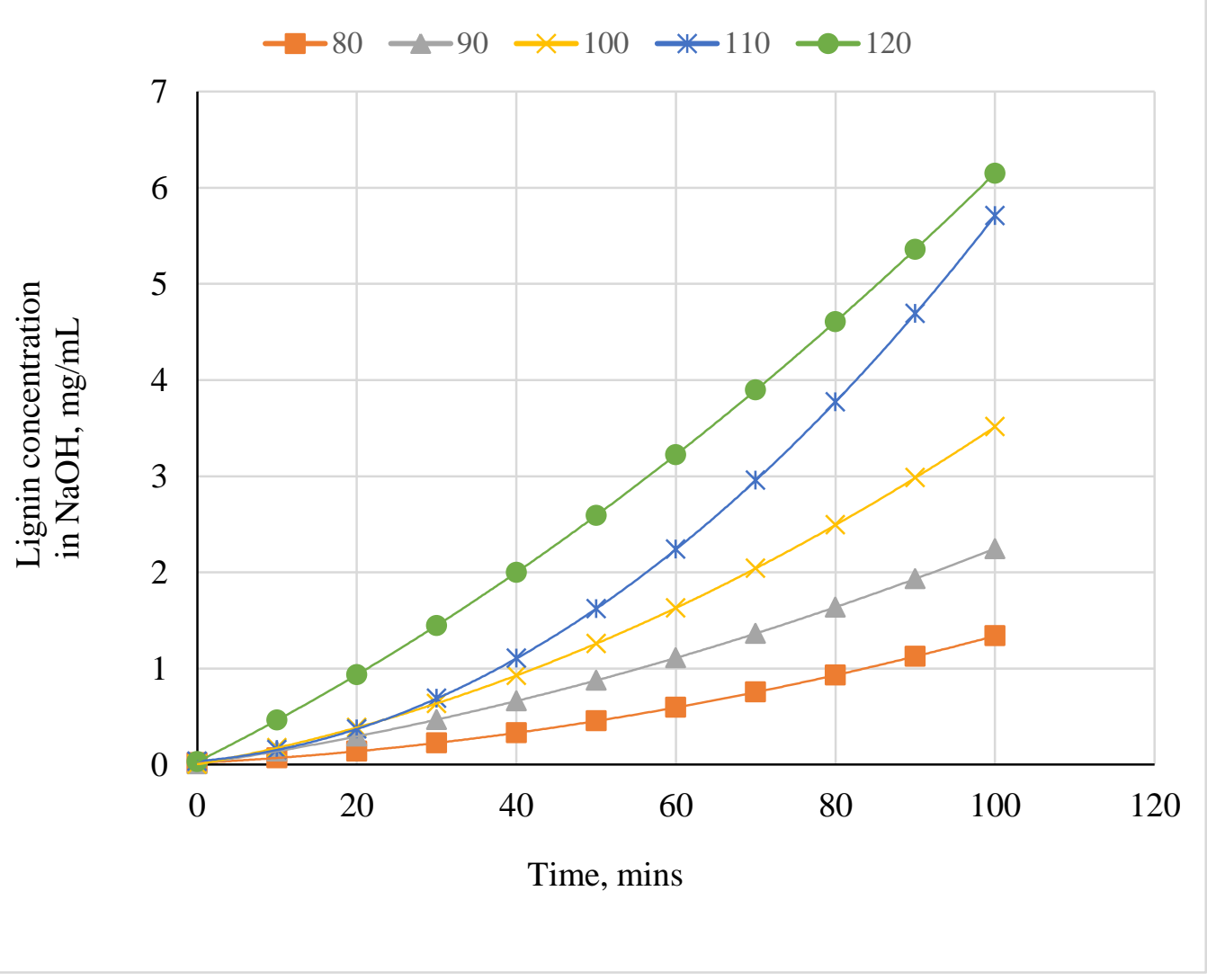

Fig. (3). Lignin Concentration in filtrate with time for $1 \mathrm{wt} / \mathrm{wt} \% \mathrm{NaOH}$ Pretreatment. 
Table 3. Variation of time and rate of reaction for $1 \mathrm{w} / \mathrm{w} \% \mathrm{NaOH}$ pretreatment of Napier grass.

\begin{tabular}{|c|c|c|c|c|c|}
\hline Time, mins & $\begin{array}{c}\Delta \mathrm{C} / \Delta \mathrm{t} \\
\mathrm{mg} / \mathrm{mL} \cdot \mathrm{min} \\
\text { at } 80^{\circ} \mathrm{C}\end{array}$ & $\begin{array}{c}\Delta \mathrm{C} / \Delta \mathrm{t} \\
\mathrm{mg} / \mathrm{mL} \cdot \mathrm{min} \\
\text { at } 90^{\circ} \mathrm{C}\end{array}$ & $\begin{array}{c}\Delta \mathrm{C} / \Delta \mathrm{t} \\
\mathrm{mg} / \mathrm{mL} \cdot \mathrm{min} \\
\text { at } 100^{\circ} \mathrm{C}\end{array}$ & $\begin{array}{c}\Delta \mathrm{C} / \Delta \mathrm{t} \\
\mathrm{mg} / \mathrm{mL} . \mathrm{min} \\
\text { at } 110^{\circ} \mathrm{C}\end{array}$ & $\begin{array}{c}\Delta \mathrm{C} / \Delta \mathrm{t} \\
\mathrm{mg} / \mathrm{mL} . \mathrm{min} \\
\text { at } 120^{\circ} \mathrm{C}\end{array}$ \\
\hline 0 & - & - & - & - & - \\
\hline 10 & 0.0051 & 0.0154 & 0.0171 & 0.0117 & 0.0432 \\
\hline 20 & 0.0069 & 0.0174 & 0.0211 & 0.0217 & 0.0472 \\
\hline 30 & 0.0087 & 0.0194 & 0.0251 & 0.0317 & 0.0512 \\
\hline 40 & 0.0105 & 0.0214 & 0.0291 & 0.0417 & 0.0552 \\
\hline 50 & 0.0123 & 0.0234 & 0.0331 & 0.0517 & 0.0592 \\
\hline 60 & 0.0141 & 0.0254 & 0.0371 & 0.0617 & 0.0632 \\
\hline 70 & 0.0159 & 0.0274 & 0.0411 & 0.0717 & 0.0672 \\
\hline 80 & 0.0177 & 0.0294 & 0.0451 & 0.0817 & 0.0712 \\
\hline 90 & 0.0195 & 0.0314 & 0.0491 & 0.0917 & 0.0752 \\
\hline 100 & 0.0213 & 0.02246 & 0.0531 & 0.1017 & 0.0792 \\
\hline
\end{tabular}

Table 4. Variation of time and natural log of concentration of lignin for $1 \mathrm{w} / \mathrm{w} \% \mathrm{NaOH}$ pretreatment of Napier.

\begin{tabular}{|c|c|c|c|c|c|}
\hline Time, mins & $\begin{array}{c}\operatorname{lnCc} \\
\mathrm{mg} / \mathrm{mL} \\
\text { at } 80^{\circ} \mathrm{C}\end{array}$ & $\begin{array}{c}\operatorname{lnCc} \\
\mathrm{mg} / \mathrm{mL} \\
\text { at } 90^{\circ} \mathrm{C}\end{array}$ & $\begin{array}{c}\operatorname{lnCc} \\
\mathrm{mg} / \mathrm{mL} \\
\text { at } 100^{\circ} \mathrm{C}\end{array}$ & $\begin{array}{c}\operatorname{lnCc} \\
\mathrm{mg} / \mathrm{mL} \\
\text { at } 110^{\circ} \mathrm{C}\end{array}$ & $\begin{array}{c}\operatorname{lnCc} \\
\mathrm{mg} / \mathrm{mL} \\
\text { at } 120^{\circ} \mathrm{C}\end{array}$ \\
\hline 0 & -3.98459 & -5.116 & -5.59942 & -3.30771 & -3.48349 \\
\hline 10 & -2.66499 & -1.96611 & -1.74469 & -1.8734 & -0.77068 \\
\hline 20 & -1.97616 & -1.22418 & -0.9527 & -0.99263 & -0.06753 \\
\hline 30 & -1.48899 & -0.75929 & -0.45146 & -0.37455 & 0.369285 \\
\hline 40 & -1.1069 & -0.41249 & -0.07505 & 0.099483 & 0.692497 \\
\hline 50 & -0.79054 & -0.13239 & 0.230079 & 0.483413 & 0.951928 \\
\hline 60 & -0.51987 & 0.10436 & 0.488396 & 0.805851 & 1.17022 \\
\hline 70 & -0.28289 & 0.310422 & 0.713293 & 1.083702 & 1.359617 \\
\hline 80 & -0.07913 & 0.493476 & 0.912965 & 1.327764 & 1.527512 \\
\hline 90 & 0.118316 & 0.658556 & 1.092829 & 1.545347 & 1.678721 \\
\hline 100 & 0.291624 & 0.809151 & 1.25667 & 1.741623 & 1.816566 \\
\hline
\end{tabular}

Table 5. Absorbance and concentration of lignin in filtrate for $3 \mathrm{w} / \mathrm{w} \% \mathrm{NaOH}$ pretreatment.

\begin{tabular}{|c|c|c|c|c|c|c|c|c|c|c|}
\hline Time & \begin{tabular}{|l|}
$\begin{array}{l}\text { Absor- } \\
\text { bance }\end{array}$ \\
\end{tabular} & $\begin{array}{c}\begin{array}{c}\text { Concen- } \\
\text { tration }(\mathrm{mg} / \mathrm{mL})\end{array} \\
\end{array}$ & \begin{tabular}{|l|}
$\begin{array}{l}\text { Absor- } \\
\text { bance }\end{array}$ \\
\end{tabular} & \begin{tabular}{|c|}
$\begin{array}{c}\text { Concen- } \\
\text { tration }(\mathbf{m g} / \mathrm{mL})\end{array}$ \\
\end{tabular} & \begin{tabular}{|c|}
$\begin{array}{c}\text { Absorb- } \\
\text { ance }\end{array}$ \\
\end{tabular} & $\begin{array}{c}\text { Concen- } \\
\text { tration }(\mathrm{mg} / \mathrm{mL}) \\
\end{array}$ & \begin{tabular}{|c|}
$\begin{array}{c}\text { Absorb- } \\
\text { ance }\end{array}$ \\
\end{tabular} & $\begin{array}{c}\text { Concen- } \\
\text { tration }(\mathrm{mg} / \mathrm{mL}) \\
\end{array}$ & $\begin{array}{c}\text { Absorb- } \\
\text { Ance }\end{array}$ & \begin{tabular}{|c|} 
Concen- \\
Tration $(\mathrm{mg} / \mathrm{mL})$ \\
\end{tabular} \\
\hline (mins) & $\left(80^{\circ} \mathrm{C}\right)$ & $\left(80^{\circ} \mathrm{C}\right)$ & $\left(90^{\circ} \mathrm{C}\right)$ & \begin{tabular}{l|l|}
$\left(90^{\circ} \mathrm{C}\right)$ \\
\end{tabular} & $\left(100^{\circ} \mathrm{C}\right)$ & $\left(100^{\circ} \mathrm{C}\right)$ & $\left(110^{\circ} \mathrm{C}\right)$ & $\left(110^{\circ} \mathrm{C}\right)$ & $\left(120^{\circ} \mathrm{C}\right)$ & $\left(120^{\circ} \mathrm{C}\right)$ \\
\hline 0 & 0 & 0 & 0 & 0 & 0 & 0 & 0 & 0 & 0 & 0 \\
\hline 30 & 0.216 & 0.432 & 0.307 & 0.61 & 0.413 & 0.826 & 0.505 & 1.01 & 0.889 & 1.778 \\
\hline 60 & 0.361 & 0.722 & 0.63 & 1.26 & 0.859 & 1.718 & 1.223 & 2.446 & 1.689 & 3.378 \\
\hline 90 & 0.779 & 1.558 & 1.105 & 2.21 & 1.438 & 2.876 & 2.541 & 5.082 & 2.884 & 5.768 \\
\hline
\end{tabular}

\subsubsection{Theoretical Estimation of the Kinetic Parameters}

Fig. (4) gives an illustration of the variation of residual lignin concentration in the filtrate with the rate of lignin removal for the pretreatment process at $80^{\circ} \mathrm{C}$. Going by equation (16), the order of the reaction is 0.50 (fractional order); the intercept simply gives $\ln k^{*}=-3.9979$ hence, $k^{*}=\ln ^{-1}(-3.9979)=0.018 \mathrm{mg}^{0.5} / \mathrm{mL}^{0.5} \cdot \mathrm{min}$ is the rate constant for lignin removal from the Napier grass sample i.e. the point on the ordinate where the concentration of lignin $=0$. 
$\ln \mathrm{Cc}, \mathrm{mg} / \mathrm{mL}$

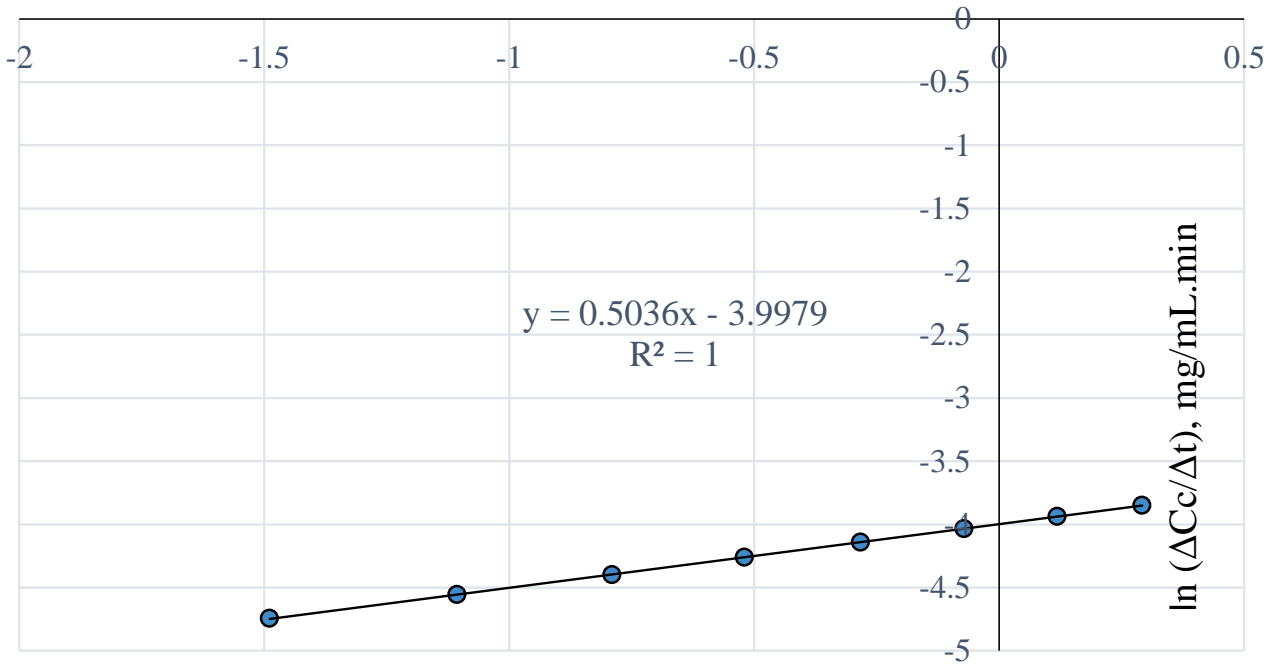

Fig. (4). $\ln (\Delta \mathrm{Cc} / \Delta \mathrm{t}) v s . \ln (\mathrm{Cc})$ for $1 \mathrm{w} / \mathrm{w} \% \mathrm{NaOH}$ pretreatment of Napier grass at $80^{\circ} \mathrm{C}$.

$\ln \mathrm{Cc}, \mathrm{mg} / \mathrm{mL}$

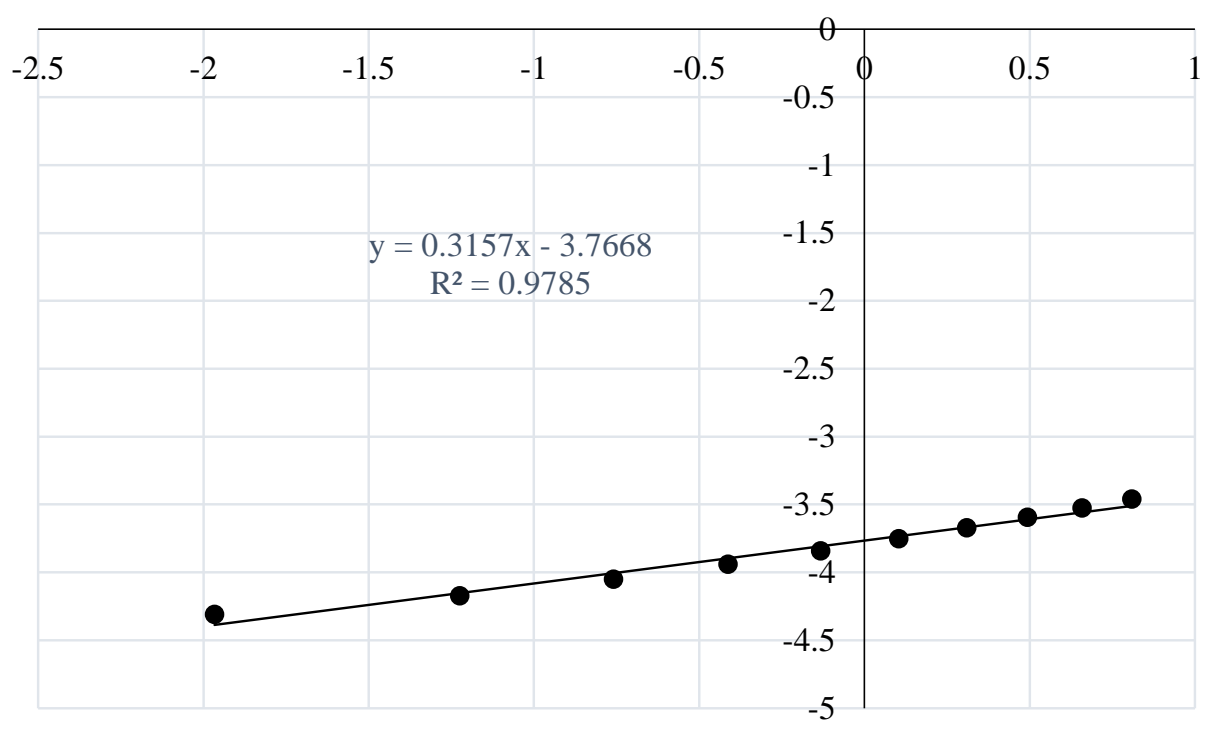

Fig. (5). $\ln (\Delta \mathrm{Cc} / \Delta \mathrm{t}) v s . \ln (\mathrm{Cc})$ for $90^{\circ} \mathrm{C}$ pretreatment. 
Again, comparing Figs. (4 and 5), the order of the reaction decreased from 0.5 to 0.3 when the temperature of the pretreatment process was increased by $10^{\circ} \mathrm{C}$ hence, the positive difference in temperature favoured higher lignin removal. Also, the lower reaction order obtained here as compared to the order at $80^{\circ} \mathrm{C}$, shows that more lignin was removed at $90^{\circ} \mathrm{C}$ since rate of reaction is a measure of the residual lignin concentration in Napier grass. The intercept simply gives $\ln k^{*}=-3.7668$ hence, $k^{*}=\ln ^{-1}(-3.2722)=0.023 \mathrm{mg}^{0.7} /(\mathrm{mL})^{0.7} \mathrm{~min}$ is the rate constant for the lignin and $\mathrm{NaOH}$ reaction for which the effect of $1 \mathrm{wt} / \mathrm{wt} \% \mathrm{NaOH}$ had no effect on the sample, because, at that point on the horizontal axis, the concentration of lignin in $\mathrm{NaOH}=0$ i.e. at that concentration, there is no feasible reaction between lignin in the substrate and the alkali. Figure (5) gives the concentration of lignin in the alkali at $90^{\circ} \mathrm{C}$.

The concentration-time relationship in Fig. (3) shows that, at $100^{\circ} \mathrm{C}$, the amount of lignin removed was $3.51 \mathrm{mg} / \mathrm{mL}$ $\mathrm{NaoH}$ after 100 mins of pretreatment. However, from Fig. (6), the order of reaction for $\mathrm{NaOH}$ and lignin in Napier grass is 0.4 with $\mathrm{R}^{2}$ value of 0.99 . Comparing this result with the previous values (i.e. reaction orders) obtained at 80 and $90^{\circ} \mathrm{C}$, the reaction order at $100^{\circ} \mathrm{C}$ is indicative of higher residual lignin in the Napier grass at 100 than at $90^{\circ} \mathrm{C} \mathrm{but}$ lower than that at $80^{\circ} \mathrm{C}$.

This could have resulted from the dissolution of other components such as extractives extracted alongside the lignin by the $\mathrm{NaOH}$ which may have posed some form of resistance to the reaction of $\mathrm{NaOH}$ and lignin. Here, the reaction pseudo rate constant is $0.031 \mathrm{mg}^{0.6} / \mathrm{L}^{0.6} \cdot \mathrm{min}$. Also, the rate of reaction of lignin and $\mathrm{NaOH}$ began to decrease after 90 mins of extraction time which may be undesirous, although, reaction rate is expected to decrease as a reaction approaches completion.

In Fig. (3), at $110^{\circ} \mathrm{C}$, the amount of lignin removed per $\mathrm{mL}$ of $\mathrm{NaOH}$ was $5.71 \mathrm{mg}$ which is $62.7 \%$ higher than the amount of lignin removed at $100^{\circ} \mathrm{C}$ and considering Fig. (7) and Tables 3-4; see also the values obtained at other temperatures, the order of the reaction increased to 0.6 for the conditions at $100^{\circ} \mathrm{C}$. In Fig. (6), the rate of lignin removal from the biomass can be determined at any specified concentration of lignin in $\mathrm{NaOH}$ solution by first obtaining the natural $\log$ of that concentration value and tracing the corresponding value on the ordinate whose $\ln ^{-1}$ or exponent is then obtained as the rate value. The value of the pseudo rate constant $=0.038 \mathrm{mg}^{0.4} / \mathrm{mL}^{0.4} \mathrm{~min}$.

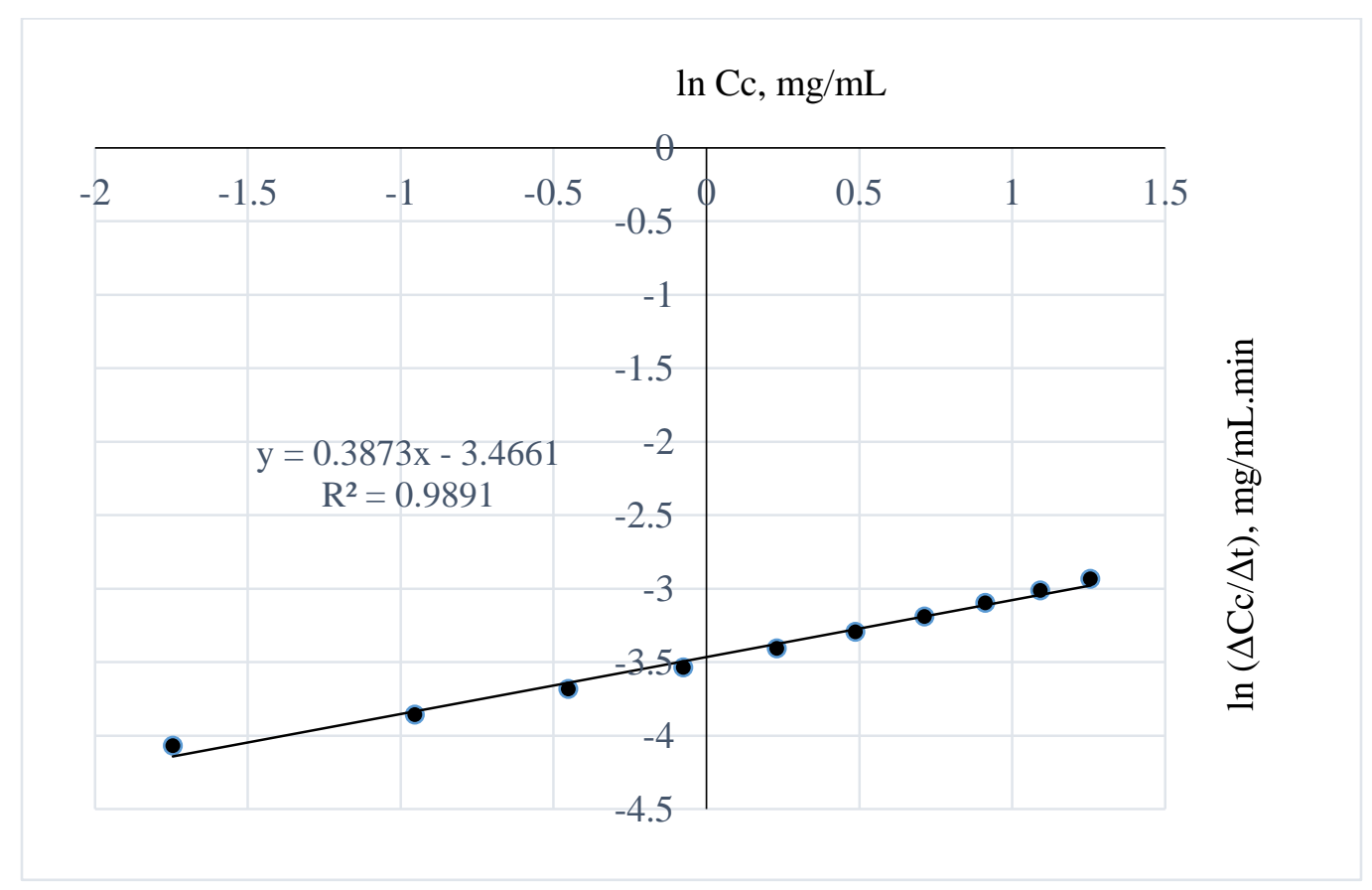

Fig. (6). $\ln (\Delta \mathrm{Cc} / \Delta \mathrm{t}) v s . \ln (\mathrm{Cc})$ for $100^{\circ} \mathrm{C}$ pretreatment. 


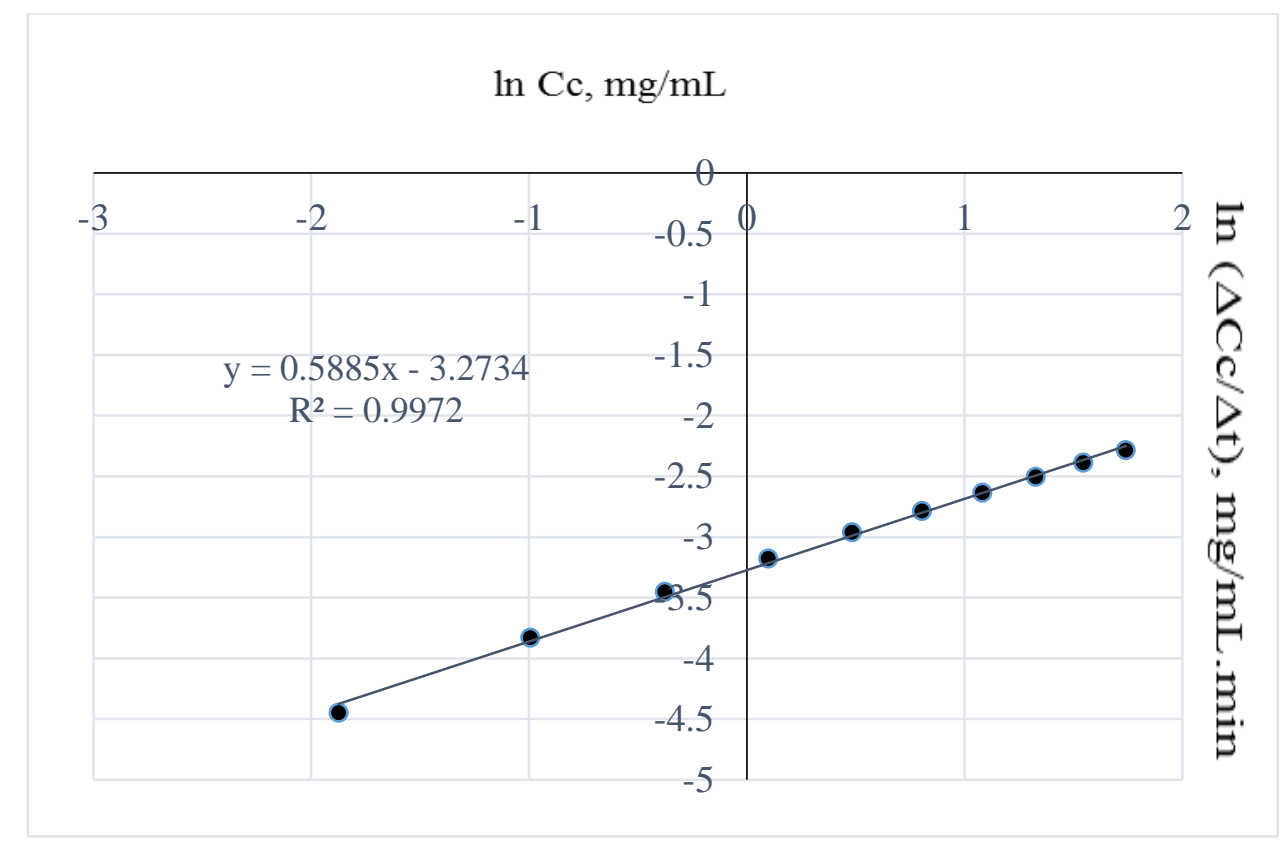

Fig. (7). $\ln (\Delta \mathrm{Cc} / \Delta \mathrm{t}) v s . \ln (\mathrm{Cc})$ for $110^{\circ} \mathrm{C}$ pretreatment.

At $120^{\circ} \mathrm{C}$, the quantity of lignin removed per $\mathrm{mL} \mathrm{NaOH}$ is $6.15 \mathrm{mg}$ (Fig. 3) which is $7.7 \%$ higher than the amount of lignin removed at $110^{\circ} \mathrm{C}$. From the plot of natural logs of rate and concentration, it is evident that the rate of lignin removal is temperature dependent, which implies that, an increase in temperature has some/little effect on the rate of reaction; the order of the reaction is 0.2 . This is further justified by the lowest slope obtained at this temperature which also implies that, the residual lignin concentration in the substrate is very low hence, high disappearance of lignin from Napier grass (Fig. 8). Furthermore, the \% extractives have no resistance to the reaction as they may have been vapourized at that temperature. Here, the value of the pseudo rate constant is $0.049 \mathrm{mg}^{0.8} / \mathrm{mL}^{0.8} \min$.

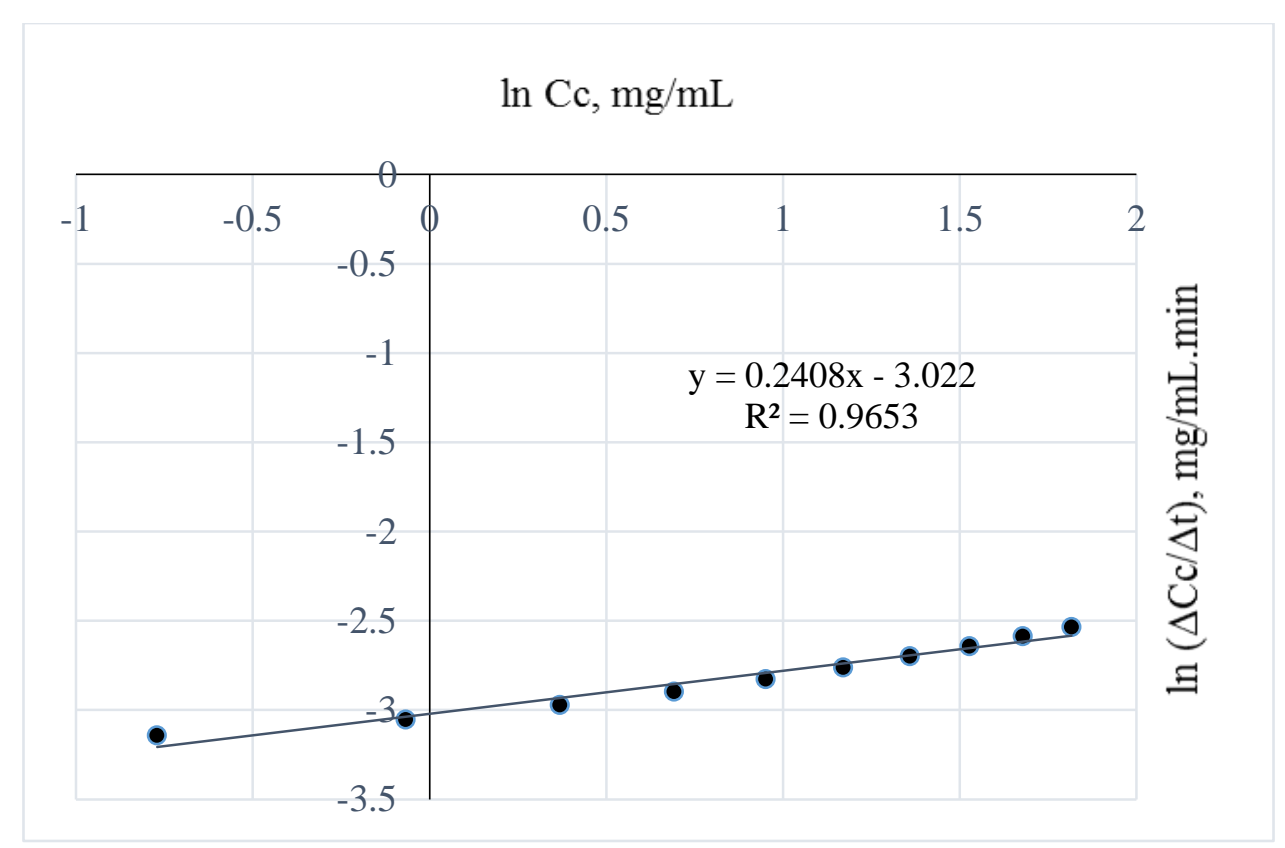

Fig. (8). $\ln (\Delta \mathrm{Cc} / \Delta \mathrm{t}) v s . \ln (\mathrm{Cc})$ for $120^{\circ} \mathrm{C}$ pretreatment of Napier grass with $1 \mathrm{w} / \mathrm{w} \% \mathrm{NaOH}$.

\subsection{Delignification Kinetics of $3 \mathrm{w} / \mathrm{w} \% \mathrm{NaOH}$}

Table 5 gives the absorbance of the $\mathrm{NaOH}$ filtrate when it was placed on the UV-Vis spectrophotometer. The 
absorbance of the $\mathrm{NaOH}$ filtrate increased with time and temperature i.e. from 0-90 mins and between $80-120^{\circ} \mathrm{C}$.

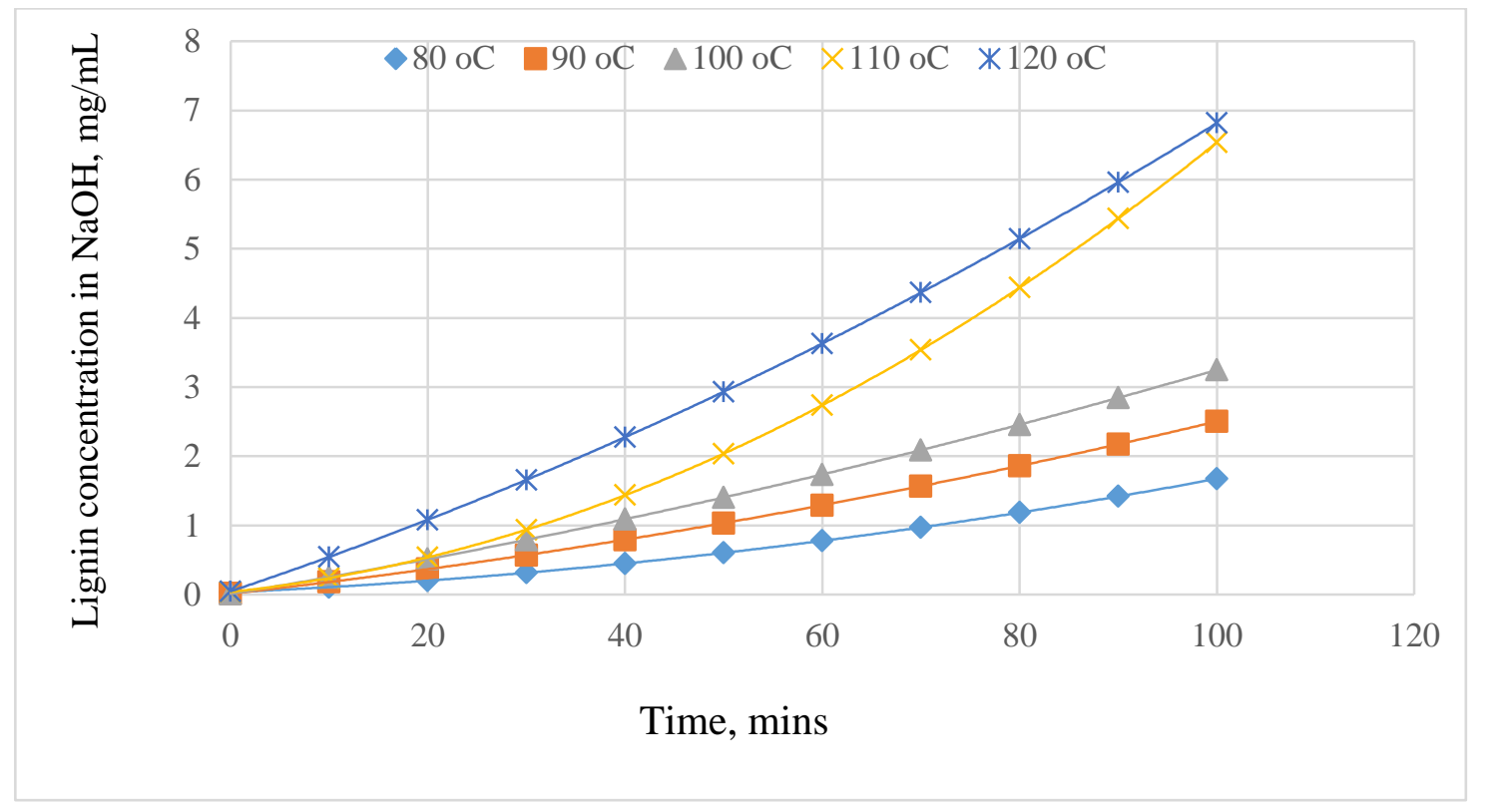

Fig. (9). Lignin Concentration in filtrate with time for $3 \mathrm{wt} / \mathrm{wt} \% \mathrm{NaOH}$ Pretreatment.

As seen for the same pretreatment time and temperature for $1 \mathrm{w} / \mathrm{w} \% \mathrm{NaOH}$ pretreatment, the concentration of lignin in solution increased with time and temperature for $3 \mathrm{w} / \mathrm{w} \% \mathrm{NaOH}$ pretreatment; this is supported by the results obtained by Wongwatanapaiboon et al. [13], although, in their work, ammonia was used to pretreat Napier grass. Here, the highest quantity of lignin removed from the Napier grass sample was recorded at $120^{\circ} \mathrm{C}$ and after 90 mins Fig. (9).

Figs. (10 and 11) are plots of the natural logs of concentration and time for $3 \mathrm{w} / \mathrm{w} \% \mathrm{NaOH}$ pretreatment of Napier grass at 80 and $90^{\circ} \mathrm{C}$ respectively. From the plots, the rate of removal of lignin from Napier grsass is not dependent on concentration since the reaction order is 1 for both cases. However, between 80 and $90^{\circ} \mathrm{C}$, lignin removal was temperature dependent as a $10^{\circ} \mathrm{C}$ rise in temperature increased the quantity of lignin removed from Napier grass with the reaction rate constants at both conditions estimated as $0 \mathrm{mg} / \mathrm{mL} . \mathrm{min}$.

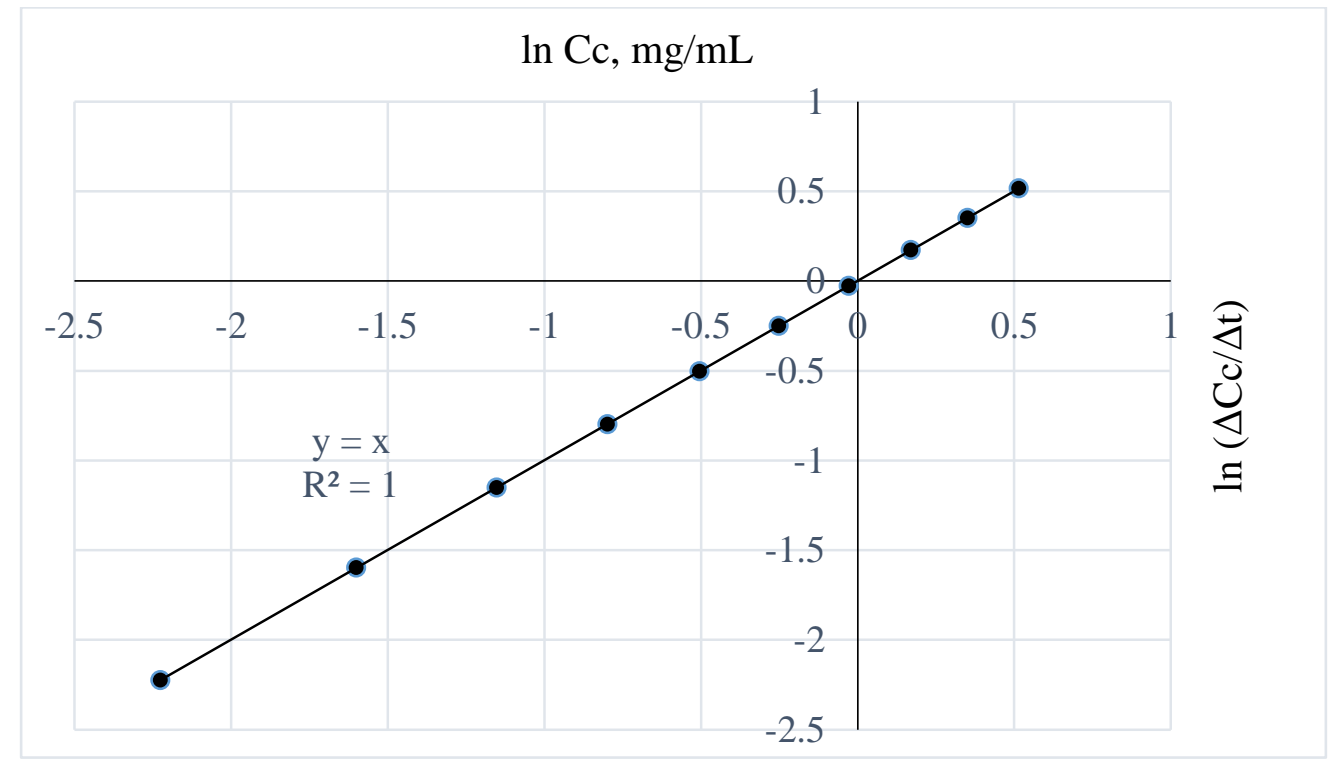

Fig. (10). $\ln (\Delta \mathrm{c} / \Delta \mathrm{t}) v s$. time for $3 \mathrm{w} / \mathrm{w} \% \mathrm{NaOH}$ pretreatment of Napier grass at $80^{\circ} \mathrm{C}$. 


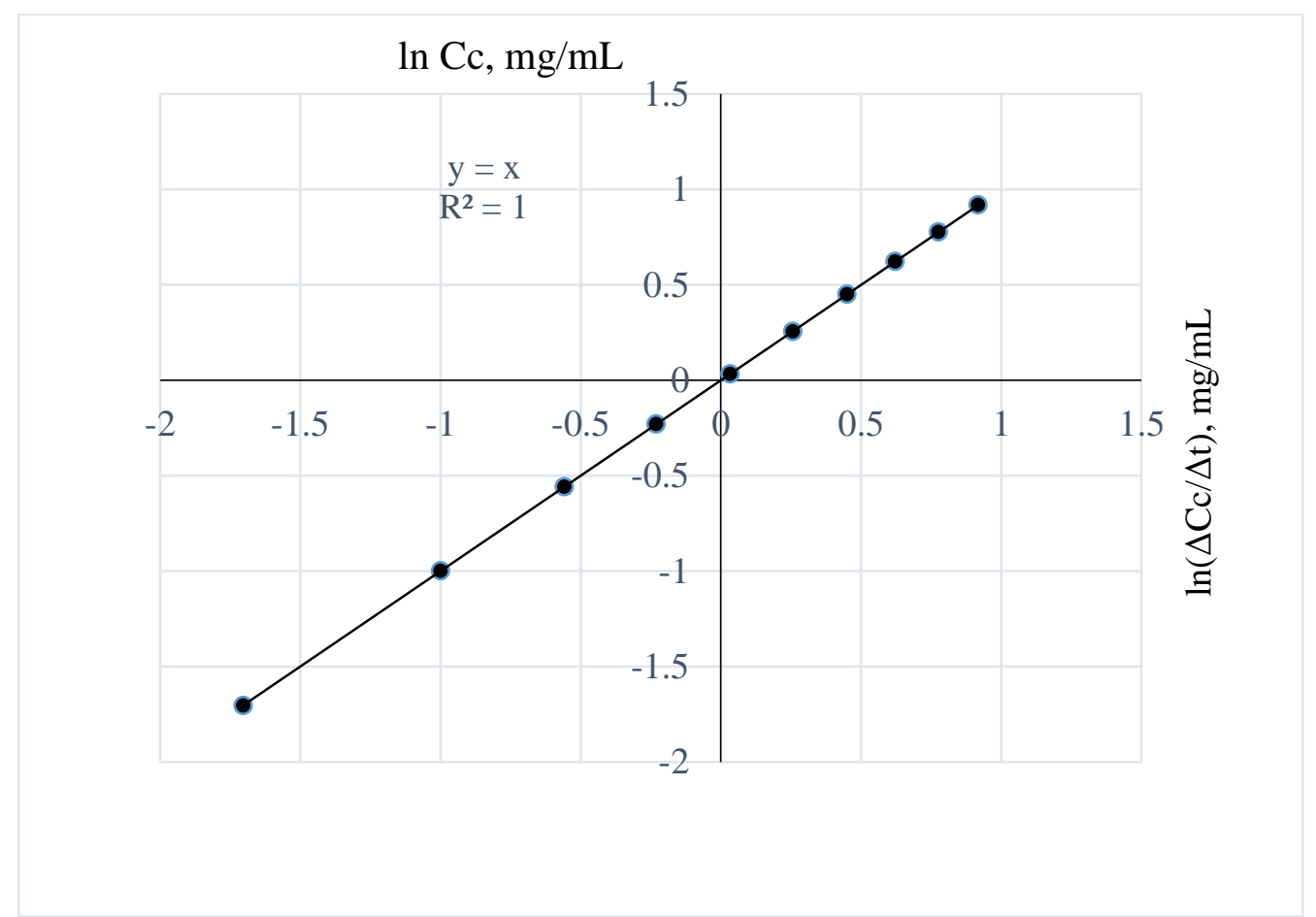

Fig. (11). $\ln (\Delta \mathrm{c} / \Delta \mathrm{t}) v s$. time for $3 \mathrm{w} / \mathrm{w} \% \mathrm{NaOH}$ pretreatment of Napier grass at $90^{\circ} \mathrm{C}$.

In Fig. (12), the residual lignin concentration is low at $100^{\circ} \mathrm{C}$ for $3 \mathrm{w} / \mathrm{w} \% \mathrm{NaOH}$ pretreatment of the sample; the order and pseudo rate constants for this pretreatment condition are 0.2 and $0.03 \mathrm{mg}^{0.8} / \mathrm{mL}^{0.8}$ min respectively; a similar reaction order was obtained for the extraction at $120^{\circ} \mathrm{C}$ and for $1 \mathrm{w} / \mathrm{w} \% \mathrm{NaOH}$. Also, the pretreatment of Napier grass using $1 \mathrm{w} / \mathrm{w} \% \mathrm{NaOH}$ at $80^{\circ} \mathrm{C}$ and $3 \mathrm{w} / \mathrm{w} \%$ at $110^{\circ} \mathrm{C}$, are indicative of similar removal rate of lignin from the sample. For the pretreatment conditions of $3 \mathrm{w} / \mathrm{w} \% \mathrm{NaOH}$, the reaction orders with their corresponding pseudo rate constants as determined from Figs. (13 and 14) are $0.5,0.045 \mathrm{mg}^{0.5} / \mathrm{mL}^{0.5} \mathrm{~min}$ and $0.2,0.053 \mathrm{mg}^{0.8} / \mathrm{mL}^{0.8}$ min respectively.

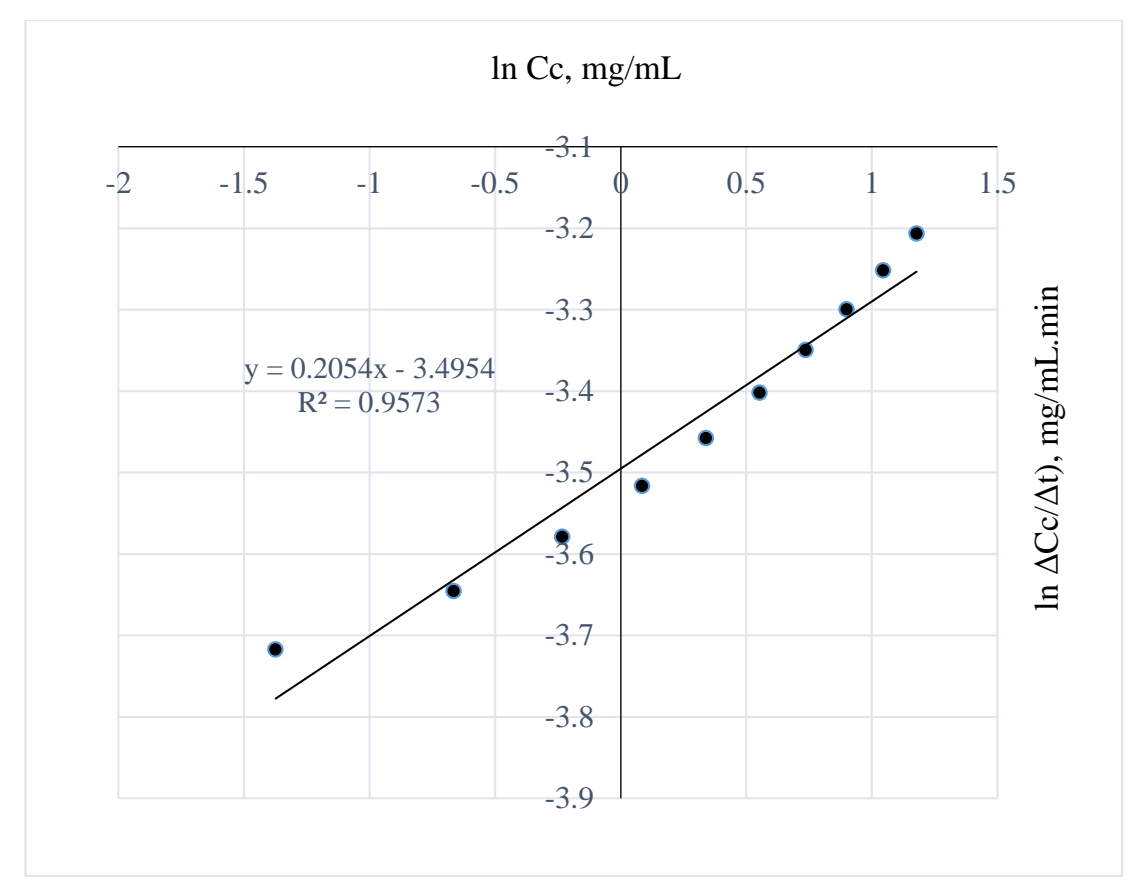

Fig. (12). $\ln (\Delta \mathrm{c} / \Delta \mathrm{t}) v s$. time for $3 \mathrm{w} / \mathrm{w} \% \mathrm{NaOH}$ pretreatment of Napier grass at $100^{\circ} \mathrm{C}$. 
$\ln \mathrm{Cc}, \mathrm{mg} / \mathrm{mL}$

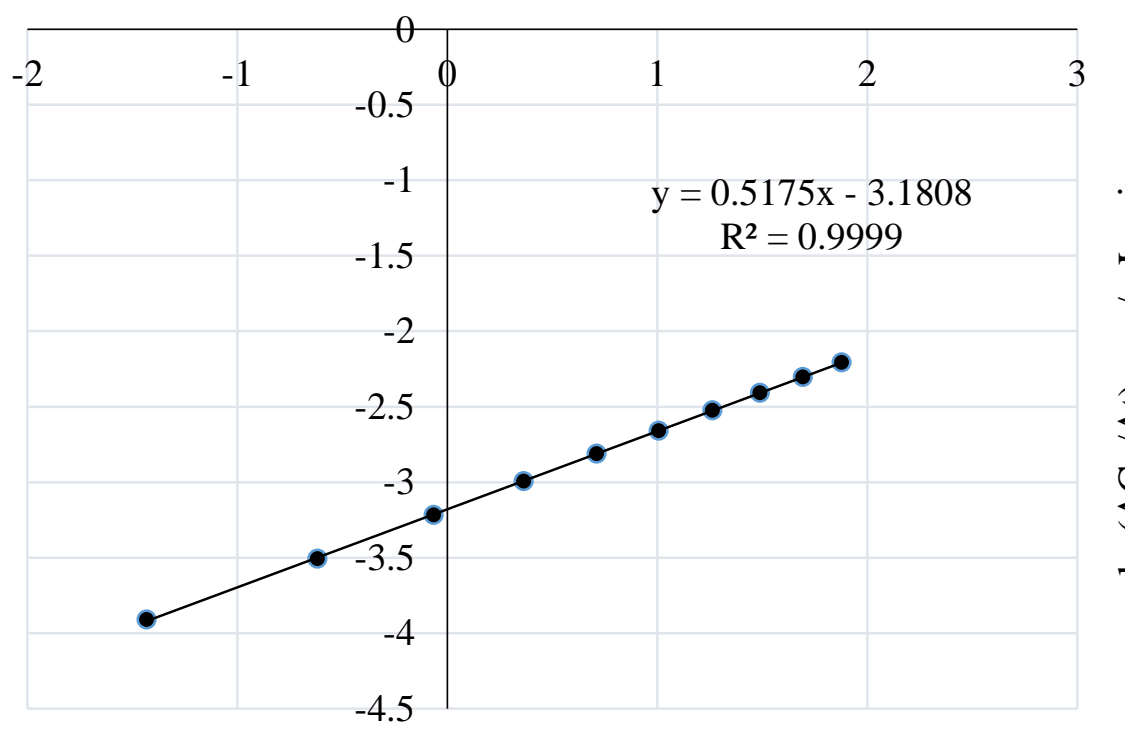

•̋

Fig. (13). $\ln (\Delta \mathrm{c} / \Delta \mathrm{t}) v s$. time for $3 \mathrm{w} / \mathrm{w} \% \mathrm{NaOH}$ pretreatment of Napier grass at $110^{\circ} \mathrm{C}$.

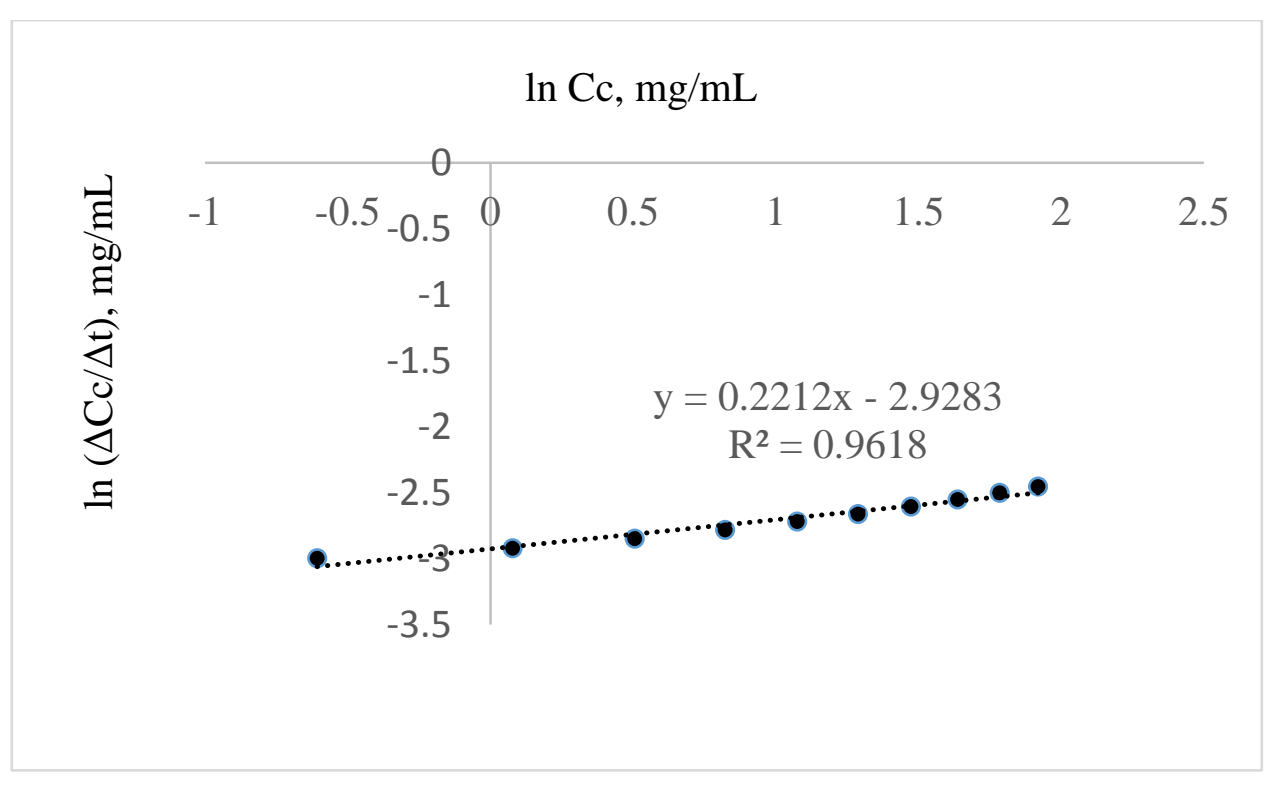

Fig. (14). $\ln (\Delta \mathrm{c} / \Delta \mathrm{t}) v s$. time for $3 \mathrm{w} / \mathrm{w} \% \mathrm{NaOH}$ pretreatment of Napier grass at $120^{\circ} \mathrm{C}$.

Table 6. Summary of pretreatment results between 80 and $120^{\circ} \mathrm{C}$.

\begin{tabular}{|c|c|c|c|c|c|c|c|}
\hline Temp. ${ }^{\circ} \mathbf{C}$ & \begin{tabular}{|c|} 
Initial \\
lignin conc. for \\
$1 \mathrm{w} / \mathrm{w} \%$
\end{tabular} & $\begin{array}{c}\text { Final lignin conc. for } \\
1 \mathrm{w} / \mathrm{w} \%\end{array}$ & $\begin{array}{c}\text { Initial lignin conc. } \\
\text { for } \\
3 \mathrm{w} / \mathbf{w} \%\end{array}$ & $\begin{array}{l}\text { Final lignin conc. } \\
\qquad 3 \mathrm{w} / \mathrm{w} \%\end{array}$ & \begin{tabular}{|}
$\Delta 1 \mathrm{w} / \mathrm{w} \%$ \\
Lignin Conc.
\end{tabular} & \begin{tabular}{|c|}
$\Delta 3 \mathrm{w} / \mathrm{w} \%$ \\
Lignin Conc.
\end{tabular} & $\begin{array}{c}\% \text { difference } \\
(\Delta 3-\Delta 1) / \Delta 1 * 100 \%\end{array}$ \\
\hline 80 & \begin{tabular}{|l|}
0.019 \\
\end{tabular} & 1.339 & 0.034 & 1.674 & 1.32 & 1.64 & 24 \\
\hline 90 & 0.006 & 2.246 & 0.014 & 2.504 & 2.24 & 2.49 & 11 \\
\hline 100 & 0.0037 & 3.5137 & 0.01 & 3.25 & 3.51 & 3.24 & 8 \\
\hline 110 & 0.0366 & 5.7066 & 0.039 & 6.5387 & 5.67 & 6.4997 & 15 \\
\hline
\end{tabular}




\begin{tabular}{|c|c|c|c|c|c|c|c|}
\hline Temp. ${ }^{\circ} \mathrm{C}$ & $\begin{array}{c}\text { Initial } \\
\text { lignin conc. for } \\
1 \mathrm{w} / \mathrm{w} \%\end{array}$ & $\begin{array}{c}\text { Final lignin conc. for } \\
1 \mathrm{w} / \mathrm{w} \%\end{array}$ & $\begin{array}{c}\text { Initial lignin conc. } \\
\text { for } \\
3 \mathrm{w} / \mathrm{w} \%\end{array}$ & $\begin{array}{c}\text { Final lignin conc. } \\
3 \mathrm{w} / \mathrm{w} \%\end{array}$ & $\mid \begin{array}{c}\Delta 1 \mathrm{w} / \mathrm{w} \% \\
\text { Lignin Conc. }\end{array}$ & $\mid \begin{array}{c}\Delta 3 \mathrm{w} / \mathrm{w} \% \\
\text { Lignin Conc. }\end{array}$ & $\begin{array}{c}\% \text { difference } \\
(\Delta 3-\Delta 1) / \Delta 1 * 100 \%\end{array}$ \\
\hline 120 & 0.0307 & 6.1507 & 0.048 & 6.8184 & 6.12 & 6.7704 & 10 \\
\hline
\end{tabular}

Considering Table 6, for all pretreatment conditions, if a benchmark is pegged at the conditions for $100^{\circ} \mathrm{C}$, based on the \%difference $\left(8,15\right.$ and $10 \%$ at 100,110 and $120^{\circ} \mathrm{C}$ respectively) obtained for the amount of lignin extracted for the pretreatment conditions of $100-120^{\circ} \mathrm{C}$ for 1 and $3 \mathrm{w} / \mathrm{w} \% \mathrm{NaOH}$, the rate of lignin removal is more temperature dependent than for conditions between 80 and $100^{\circ} \mathrm{C}$. Also, the rate of lignin removal is more concentration dependent between $80-100^{\circ} \mathrm{C}$ than for conditions at $100-120^{\circ} \mathrm{C}$ due to the higher \%difference (i.e. 24,11 and $8 \%$ for 80,90 and $100^{\circ} \mathrm{C}$ respectively) in concentration of lignin recorded, which is corroborated by the findings in [31]. See Table 6 for a summary of the pretreatment results between $80-120^{\circ} \mathrm{C}$.

Considering the initial and final pretreatment conditions for the Napier grass sample, the results in Table $\mathbf{6}$ further justify the best pretreatment conditions as already mentioned and are in agreement with the findings of Mafuleka and Kanal [21] at increased pretreatment temperature. However, there seems to be some peculiarity in the results obtained i.e. the results clearly indicate that, the pretreatment conditions for $3 \mathrm{w} / \mathrm{w} \% \mathrm{NaOH}$ at $100^{\circ} \mathrm{C}$ and $120^{\circ} \mathrm{C}$ gave the least $\%$ difference of 8 and $10 \%$ respectively, which confirms the level of similarity between both pretreatment conditions hence, the established rate law at the condition for the highest lignin extraction is given as: $-r_{A}=k^{*} C_{A}^{0.2}$

Furthermore, the results from pretreatment at $120^{\circ} \mathrm{C}$ for $3 \mathrm{w} / \mathrm{w} \%$ concentration of $\mathrm{NaOH}$, reveal that the efficiency of lignin removal from the Napier grass sample was $72.2 \%$ based on the Acid Insoluble Lignin (AIL) content of the biomass but considering the total amount of lignin in the material, the delignification efficiency is about $59.2 \%$ for a pretreatment time of 90 minutes.

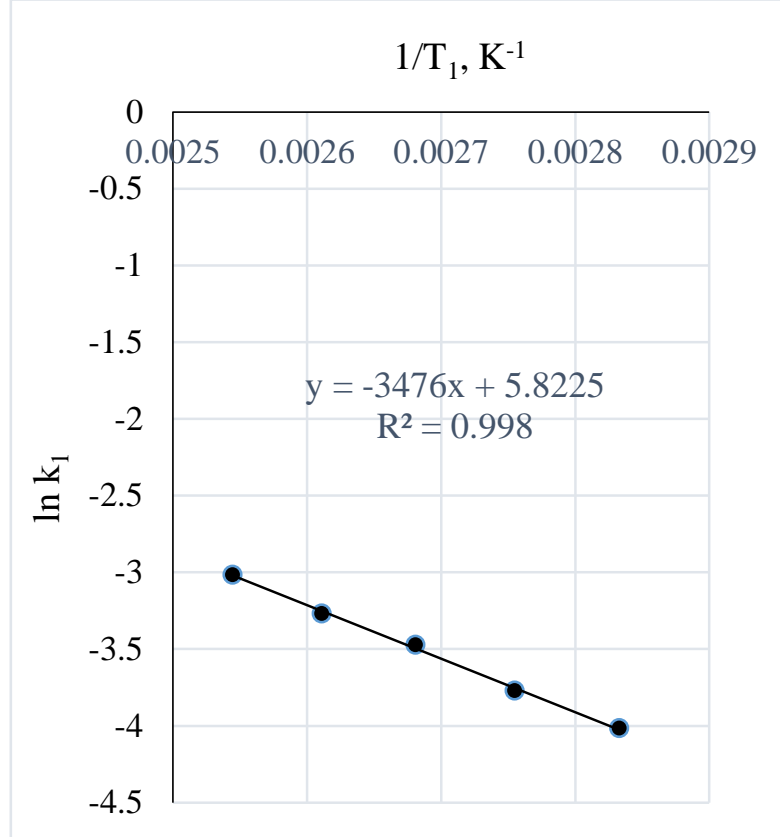

(a)

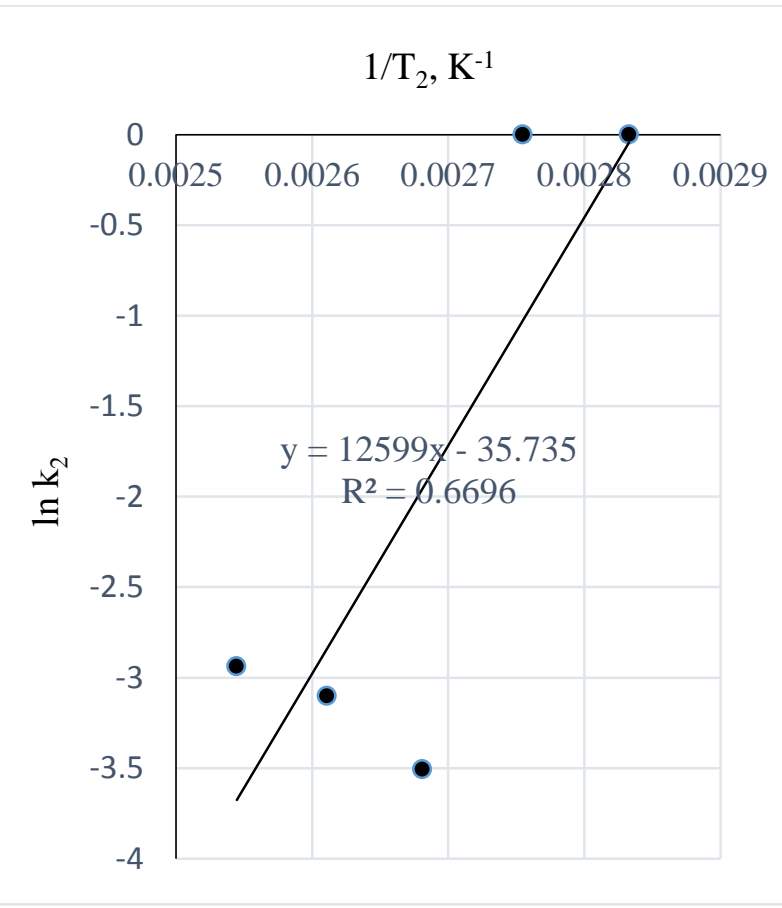

(b)

Fig. (15). a. $\ln \mathrm{k}_{1} v s .1 / \mathrm{T}_{1}$, b. $\ln \mathrm{k}_{2} v s .1 / \mathrm{T}_{2}$

The estimated $\mathrm{k}$ pseudo rate constants for the reaction are as given in Table 7. Using Equation (9), A plot of $\ln k$ for $1 \mathrm{w} / \mathrm{w} \% \mathrm{NaOH} v s .1 / \mathrm{T}$ gives $-\mathrm{E}_{\mathrm{A}} / \mathrm{R}$ as slope and $\ln \mathrm{k}_{\mathrm{o}}$ as intercept while, a plot of $\ln \mathrm{k}$ for $3 \mathrm{w} / \mathrm{w} \% \mathrm{NaOH} v s .1 / \mathrm{T}$ gives $-\mathrm{E}_{\mathrm{A}} / \mathrm{R}$ and $\ln \mathrm{k}_{\mathrm{o}}$ as intercept. 
Table 7. Pseudo rate constants for the pretreatment conditions.

\begin{tabular}{|c|c|c|}
\hline $\boldsymbol{T},{ }^{\circ} \mathbf{C}$ & $\boldsymbol{k}^{*}$ for $\mathbf{1} \mathbf{w} / \mathbf{w} \mathbf{\%}$ pretreatment & $\boldsymbol{k}$ * for 3 w/w \% pretreatment \\
\hline 80 & 0.018 & 0 \\
\hline 90 & 0.023 & 0 \\
\hline 100 & 0.031 & 0.03 \\
\hline 110 & 0.038 & 0.045 \\
\hline 120 & 0.049 & 0.053 \\
\hline
\end{tabular}

In Figs. (15a and $\mathbf{b}),-\mathrm{E}_{\mathrm{A}} / \mathrm{R}=-3476$ and 12599 with $\mathrm{R}^{2}$ values of 0.99 and 0.67 giving $\mathrm{E}_{\mathrm{A}}$ values of 143404.9 and $-519780.7 \mathrm{~J} / \mathrm{g} . \mathrm{K}$, respectively. $1 \mathrm{~g}$ of lignin to mole $=1 / 343 \mathrm{gmol}^{-1}($ molar mass of lignin $)=0.002915 \mathrm{~mole}$.

Since 0.002915 mole of lignin $=1 \mathrm{~g}$ of lignin and,

1 mole of lignin $=1 / 0.002915=343 \mathrm{~g}$ of lignin

$\therefore \mathrm{R}=8.314 \mathrm{~J} / \mathrm{mol} . \mathrm{K}=8.314 \mathrm{~J} / 343 \mathrm{~g} . \mathrm{K}=0.024239 \mathrm{~J} / \mathrm{g} . \mathrm{K}$

Hence $\mathrm{E}_{\mathrm{A}}=3476 / 0.024239=143404.9 \mathrm{~J} / \mathrm{g} . \mathrm{K}$ and $-12599 / 0.024239=-519780.7 \mathrm{~J} / \mathrm{g} . \mathrm{K}$

This then reveals that the reaction is endothermic for the reaction conditions of $1 \mathrm{w} / \mathrm{w} \% \mathrm{NaOH}$ pretreatment and exothermic for the pretreatment conditions of $3 \mathrm{w} / \mathrm{w} \% \mathrm{NaOH}$ which is indicative of the ability of the reactants to generate the heat required for the process hence, there was excess heat during the reaction of $3 \mathrm{w} / \mathrm{w} \% \mathrm{NaOH}$ and Lignin. However, it is therefore recommended to carry out further research to investigate this ability of $\mathrm{NaOH}$ to react with lignin in Napier grass without any additional heat for $3 \mathrm{w} / \mathrm{w} \% \mathrm{NaOH}$ and higher concentrations.

Considering the results shown in Tables 1-8, an efficiency of $72 \%$ suggests the need for: a hybridized $\mathrm{NaOH}$ or combined pretreatment technique, longer pretreatment time or pretreatment at higher temperatures if a higher efficiency is desired. However, in this work, the pretreatment time was extended for the condition that gave the highest lignin removal. The results for time extension of the delignification process is as contained in Table 2; the variations of concentration of lignin in $\mathrm{NaOH}$ with the corresponding absorbance as obtaineded on the UV mass spectrometer were also recorded.

Table 8. Variation of time and natural $\log$ of reaction rate for $1 \mathrm{w} / \mathrm{w} \% \mathrm{NaOH}$ pretreatment of Napier grass.

\begin{tabular}{|c|c|c|c|c|c|}
\hline Time, mins & $\begin{array}{l}\ln (\Delta C / \Delta t) \\
\mathrm{mg} / \mathrm{mLmin} \\
\text { at } 80^{\circ} \mathrm{C}\end{array}$ & $\begin{array}{l}\ln (\Delta C / \Delta t) \\
\mathrm{mg} / \mathrm{mLmin} \\
\text { at } 90^{\circ} \mathrm{C}\end{array}$ & $\begin{array}{c}\ln (\Delta C / \Delta t) \\
m g / m L m i n \\
\text { at } 100^{\circ} \mathrm{C}\end{array}$ & $\begin{array}{c}\ln (\Delta C / \Delta t) \\
\mathrm{mg} / \mathrm{mLmin} \\
\text { at } 110^{\circ} \mathrm{C}\end{array}$ & $\begin{array}{c}\ln \Delta \mathrm{C} / \Delta \mathrm{t}) \\
\mathrm{mg} / \mathrm{mLmin} \\
\text { at } 120^{\circ} \mathrm{C}\end{array}$ \\
\hline 0 & - & - & - & - & - \\
\hline 10 & -5.27851 & -4.17339 & -4.06868 & -4.44817 & -3.142 \\
\hline 20 & -4.97623 & -4.05129 & -3.85848 & -3.83044 & -3.05336 \\
\hline 30 & -4.74443 & -3.94248 & -3.68489 & -3.45144 & -2.97202 \\
\hline 40 & -4.55638 & -3.84436 & -3.53702 & -3.17725 & -2.89679 \\
\hline 50 & -4.39816 & -3.75502 & -3.40822 & -2.9623 & -2.82683 \\
\hline 60 & -4.26158 & -3.67301 & -3.29414 & -2.78547 & -2.76145 \\
\hline 70 & -4.14144 & -3.59721 & -3.19175 & -2.63526 & -2.70008 \\
\hline 80 & -4.03419 & -3.52676 & -3.09887 & -2.5047 & -2.64226 \\
\hline 90 & -3.93734 & -3.46095 & -3.0139 & -2.38923 & -2.5876 \\
\hline 100 & -3.84905 & -3.79602 & -2.93558 & -2.28573 & -2.53578 \\
\hline
\end{tabular}

\subsection{Optimum Pretreatment Time for $3 \mathrm{w} / \mathrm{w} \% \mathrm{NaOH}$ Pretreatment of the Napier Grass}

For all the pretreatment conditions considered, i.e. between $80-120^{\circ} \mathrm{C}$, the $3 \mathrm{w} / \mathrm{w} \% \mathrm{NaOH}$ pretreatment of the Napier grass at $120^{\circ} \mathrm{C}$ gave the highest amount of lignin removed after 100 mins (Table 5) hence, in order to establish the best/optimum pretreatment time for the process, the pretreatment time was extended at a constant time interval of 30 minutes and it was observed that, for an optimum absorbance of 52.98, an optimum pretreatment time of $17.5 \mathrm{~h}$ is required to completely remove the AIL from the Napier grass (Table 2); the reports in [32] also confirms that higher absorbance values can be obtained for t-butyl-phenol or t-butyl phenoxide in an alkaline medium such as methanol at a 
wavelength of $203 \mathrm{~nm}$. Also, the reaction order for the pretreatment process is closely related to a pseudo-zero order kinetics as shown in Fig. (15). The plot in Fig. (15) was made by first making a plot of Ce vs. t.

The appropriate polynomial equation was then displayed; this approach is valid and adopted due to the close data points generated from the progressive search for a steady state condition. Afterwards, the equation of the polynomial was differentiated to give the change in concentration wrt to time and because there are several close data points, few data points at a time interval of 120 minutes were selected and the plot of $\ln (\Delta \mathrm{Cc} / \Delta \mathrm{t}) v \mathrm{~s}$. $\operatorname{lnCc}$ was then obtained with the final equation displayed within some limits of accuracy i.e. with $\mathrm{R}^{2}$ value of 0.86 .

In Fig. (1), it is evident that the initial amount of lignin in $1.0 \mathrm{~g}$ of Napier grass is $0.0945 \mathrm{~g}$ but as the reaction approached completion Table (8), only $0.085 \mathrm{~g}$ was accounted for which shows that an efficiency of $90 \%$ was obtained for the removal of AIL with only $10 \%$ error which may have resulted from over saturation of the $\mathrm{NaOH}$ with lignin or inability of the $\mathrm{NaOH}$ to come in contact with the lignin as a result of the barrier to further dissolution of the lignin in $\mathrm{NaOH}$. Furthermore, it is possible that the unreacted AIL and ASL were bound in the lignin matrix such that in order to stimulate further conversion or reaction of lignin with $\mathrm{NaOH}$, the concentration of $\mathrm{NaOH}$ would have to be increased. Considering the total amount of lignin in $1 \mathrm{~g}$ of the grass, the delignification process is $73 \%$ efficient owing to the ASL in the sample in addition to the unreacted lignin or residual AIL in the Napier grass. The estimated order of the reaction is -0.08 (Fig. 16) and since the order of a reaction cannot be negative, it then implies that the reaction order is approximately zero which is also valid as confirmed by the downward slope of the graph or negative value of $\mathrm{k}$ since for a zero order reaction, $-\mathrm{r}_{\mathrm{A}}=\mathrm{k}$ which gives, $\mathrm{C}_{\mathrm{A}}=\mathrm{C}_{\mathrm{AO}}-\mathrm{kt}$; where $-\mathrm{r}_{\mathrm{A}}=$ reaction rate, $\mathrm{C}_{\mathrm{A}}=$ concentration of lignin in $\mathrm{NaOH}$ at time $\mathrm{t}, \mathrm{C}_{\mathrm{Ao}}=$ initial concentration of lignin at time $\mathrm{t}=0$ and $\mathrm{k}=$ the velocity constant for the reaction; meaning that at longer times, the reaction is not affected by concentration of $\mathrm{NaOH}$ which also confirms that the reaction of lignin and $\mathrm{NaOH}$ is pseudo zero order or pseudo fractional order with respect to $\mathrm{NaOH}$ as seen for conditions prior steady state condition..

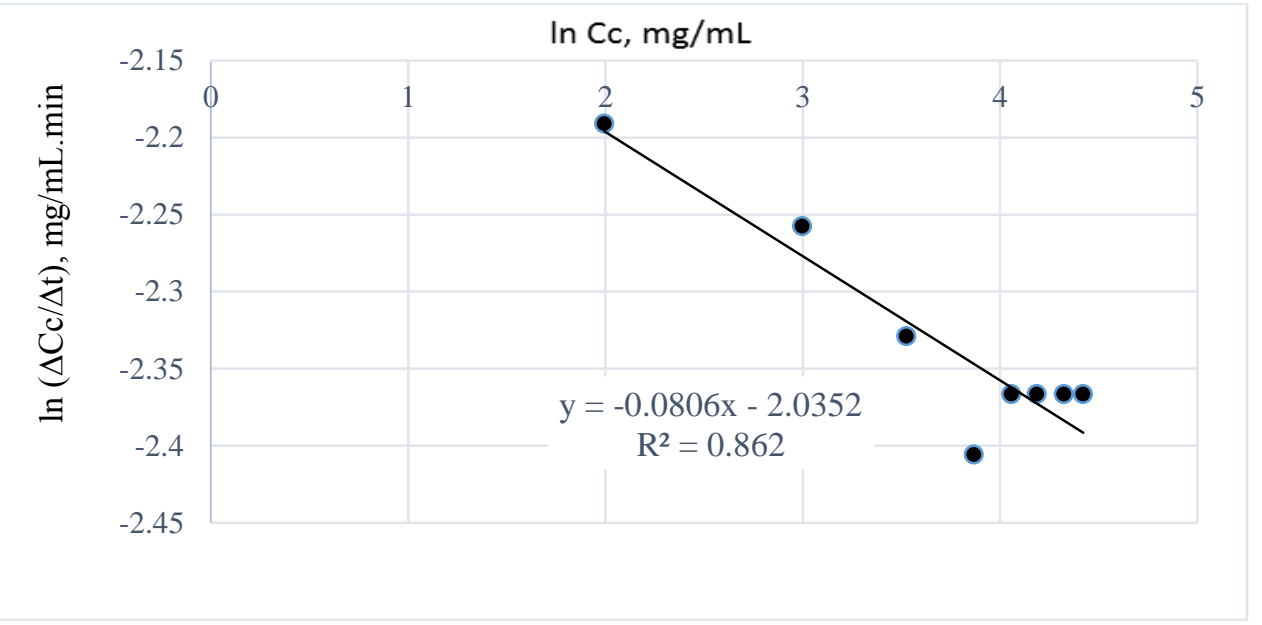

Fig. (16). $\ln (\Delta \mathrm{Cc} / \Delta \mathrm{t}) v s . \ln \mathrm{Cc}$ for $3 \mathrm{w} / \mathrm{w} \% \mathrm{NaOH}$ pretreatment at $120^{\circ} \mathrm{C}$ and optimum time of $17.5 \mathrm{~h}$.

\section{CONCLUSION}

The rate of lignin extraction by $\mathrm{NaOH}$ in Napier grass can be accurately described using the Differential Technique combined with the Ostwald Method of Isolation based on the limits of accuracies of the regression lines obtained during the analysis hence, the rate law for the process at the best pretreatment conditions i.e. $3 \mathrm{w} / \mathrm{w} \% \mathrm{NaOH}$ pretreatment of the Napier grass at $120^{\circ} \mathrm{C}$ is given as $-r_{L}=\mathrm{k}^{*} \mathrm{C}_{\mathrm{L}}{ }^{\alpha}$ where $\alpha$ lies between 0 and 0.2 hence, the reaction of lignin in Napier grass and $\mathrm{NaOH}$ obeys a pseudo-fractional order kinetics which may no longer be influenced by $\mathrm{NaOH}$ concentration but is only affected by temperature at longer reaction time. The optimum pretreatment time (steady state condition) required for complete removal of AIL in $1 \mathrm{~g}$ of the Napier grass sample was found to be $17.5 \mathrm{~h}$. The results show that the delignification process is more energy intensive (i.e. endothermic) with respect to $1 \mathrm{w} / \mathrm{w} \% \mathrm{NaOH}$ pretreatment of Napier grass but less energy intensive (i.e. exothermic) for pretreatment conditions of $3 \mathrm{w} / \mathrm{w} \% \mathrm{NaOH}$ pretreatment of Napier grass. The rate of lignin removal was higher for $3 \mathrm{w} / \mathrm{w} \%$ than for $1 \mathrm{w} / \mathrm{w} \% \mathrm{NaOH}$ pretreatment of the Napier grass. Also, lignin extraction at $80^{\circ} \mathrm{C}$ seems to be most influenced by change in $\mathrm{NaOH}$ concentration from 1 to $3 \mathrm{w} / \mathrm{w} \%$ since the highest \%difference in lignin concentration in the extract was obtained at $80^{\circ} \mathrm{C}$ considering reactions between 
80 and $120^{\circ} \mathrm{C}$, while the \%difference was lowest for lignin extraction at $100^{\circ} \mathrm{C}$ (Table 6); this gives a clue of the weaker influence the change in $\mathrm{NaOH}$ concentration has on the lignin in the extraction process hence, the reaction at $100^{\circ} \mathrm{C}$ seems to be the least influenced by change in concentration since it gives the least \%difference or change in lignin concentration for all pretreatment conditions.

\section{CONSENT FOR PUBLICATION}

Not applicable.

\section{CONFLICT OF INTEREST}

The authors declare no conflict of interest, financial or otherwise.

\section{ACKNOWLEDGEMENTS}

The authors wish to appreciate Covenant University for her sponsorship as well as granting access to facilities when needed. The authors appreciate Sanni Samuel for planning the project, executing it, preparing the manuscript and detailing on the reaction kinetics. Olasubomi Akinrinola for carrying out the experimental works, Esther Yusuf and Omololu Fabgiele for assisting with the analyses and Oluranti Agboola for contributing to the kinetic studies and editing of the manuscript.

\section{REFERENCES}

[1] D. Alexander, D. Richard, G. Scott, and P. Ryan, "Enzymatic Hydrolysis of Cellulosic Biomass for the Production of Second Generation Biofuels", Masters Dissertation, Worcester Polytechnic Institute, Worcestershire, U.K, 2009.

[2] N. Andersen, and E.H. Stenby, Enzymatic Hydrolysis of Cellulose: Experimental and Modelling Studies., Technical University of Denmark: Denmark, Germany, 2007.

[3] P.C. Badger, Ethanol from Cellulose: A General Review., ASHS Press: Alexandria, Virginia, 2002.

[4] J. Wongwatanapaiboon, K. Kangvansaichol, V. Burapatana, R. Inochanon, P. Winayanuwattikun, T. Yongvanich, and W. Chulalaksananukul, The Potential of Cellulosic Ethanol Production from Grasses in Thailand., BMRI, 2012. Internet

[5] N. Mosier, C. Wyman, B. Dale, R. Elander, Y.Y. Lee, M. Holtzapple, and M. Ladisch, "Features of promising technologies for pretreatment of lignocellulosic biomass", Bioresour. Technol., vol. 96, no. 6, pp. 673-686, 2005. [http://dx.doi.org/10.1016/j.biortech.2004.06.025] [PMID: 15588770]

[6] L. Fan, M.M. Gharpuray, and Y.H. Lee, Enzymatic Hydrolysis Cellulose Hydrolysis., Springer: Berlin Heidelberg, Germany, 1987. [http://dx.doi.org/10.1007/978-3-642-72575-3]

[7] R. Kataria, R. Ruhal, R. Babu, and S. Ghosh, "Saccharification of Alkali Treated Biomass of Kans Grass Contributes Higher Sugar in Contrast to Acid Treated Biomass", Chem. Eng. J., vol. 230, pp. 36-47, 2013. [http://dx.doi.org/10.1016/j.cej.2013.06.045]

[8] K. Yan, F. Liu, Q. Chen, M. Ke, X. Huang, W. Hu, B. Zhou, X. Zhang, and H. Yu, "Pyrolysis characteristics and kinetics of lignin derived from enzymatic hydrolysis residue of bamboo pretreated with white-rot fungus", Biotechnol. Biofuels, vol. 9, no. 9, p. 76, 2016. [http://dx.doi.org/10.1186/s13068-016-0489-y] [PMID: 27034714]

[9] S. Singh, G. Cheng, N. Sathitsuksanoh, D. Wu, P. Varanasi, A. George, V. Balan, X. Gao, R. Kumar, B.E. Dale, C.E. Wyman, and B.A. Simmons, "Comparison of Different Biomass Pretreatment Techniques and Their Impact on Chemistry and Structure", Front. Energy Res., vol. 2, no. 62, pp. 1-12, 2015.

[10] H.L. Trajano, N.L. Engle, M. Foston, A.J. Ragauskas, T.J. Tschaplinski, and C.E. Wyman, "The fate of lignin during hydrothermal pretreatment", Biotechnol. Biofuels, vol. 6, no. 1, p. 110, 2013. [http://dx.doi.org/10.1186/1754-6834-6-110] [PMID: 23902789]

[11] J. Shi, G.B. Hodge, S.W. Pryor, and Y. Li, Pretreatment of Lignocellulosic Biomass, BEEMS Module B1 lecture notes, sponsored by: USDA Higher Education Challenger Program 2009-38411-19761, slides 1-58, 2009.

[12] A.O. Ayeni, J.A. Omoleye, F.K. Hymore, and R.A. Pandey, "Effective Alkaline Peroxide Pretreatment of Shea Tree Sawdust for the Production of Biofuels: Kinetics of Delignification and Enzymatic Conversion to Sugar and Subsequent Production of Ethanol by Fermentation using Saccharomyces Cerevisiae", Braz. J. Chem. Eng., vol. 33, no. 1, pp. 33-45, 2016. [http://dx.doi.org/10.1590/0104-6632.20160331s20140258]

[13] J. Gao, X. Yang, J. Wan, Y. He, C. Chang, X. Ma, and J. Bai, "Delignification Kinetics of Corn Stover with Aqueous Ammonia Soaking Pretreatment", Bioresources.com, vol. 11, no. 1, pp. 2403-2416.

[14] Y. Ji, S. Viamajala, M.J. Selig, T. Vinzand, and M.P. Tucker, "Comparison of the Kinetics of Xylose and Lignin Removal During Hot Water and Dilute Acid Pretreatment of Corn Stover Using a Continuous Flow-Through Reactor", In: Presented at the 31st Symposium on Biotechnology for Fuels and Chemicals NREL, U.S. Department of Energy, San Francisco California, USA, 2009. 
[15] R. Kumar, F. Hu, C.A. Hubbell, A.J. Ragauskas, and C.E. Wyman, "Comparison of laboratory delignification methods, their selectivity, and impacts on physiochemical characteristics of cellulosic biomass", Bioresour. Technol., vol. 130, no. 130, pp. 372-381, 2013. [http://dx.doi.org/10.1016/j.biortech.2012.12.028] [PMID: 23313683]

[16] X. Meng, Q. Sun, M. Kosa, F. Huang, Y. Pu, and A.J. Ragauskas, "Physicochemical Structural Changes of Poplar and Switch Grass during Biomass Pretreatment and Enzymatic Hydrolysis", Sustainable Chemistry and Engineering, 2016.

[17] M. Soleimani, L.G. Tabil, and C. Niu, "Delignification of Intact and Cellulosic Coproduct of Acid-Catalyzed Hydrolysis", AIChE J., vol. 61, no. 6, pp. 1783-1791, 2015. [http://dx.doi.org/10.1002/aic.14794]

[18] G. Brodeur, E. Yau, K. Badal, J. Collier, K.B. Ramachandran, and S. Ramakrishnan, "Chemical and physicochemical pretreatment of lignocellulosic biomass: A review", Enzyme Res., vol. 2011, p. 787532, 2011. [http://dx.doi.org/10.4061/2011/787532] [PMID: 21687609]

[19] X. Zhou, "The Structural Changes of Lignin at Different Stages of Growth of Napier Grass", Drenwo, vol. 60, p. 199, 2017. [http://dx.doi.org/10.12841/wood.1644-3985.177.03]

[20] F.R. Amin, H. Khalid, H. Zhang, S.U. Rahman, R. Zhang, G. Liu, and C. Chen, "Pretreatment methods of lignocellulosic biomass for anaerobic digestion", AMB Express, vol. 7, no. 1, p. 72, 2017. [http://dx.doi.org/10.1186/s13568-017-0375-4] [PMID: 28353158]

[21] S. Mafuleka, and E.G.B. Kana, "Modelling and Optimization of Xylose and Glucose Production from Napier Grass Using Hybrid Pretreatment Techniques", Biomass Bioenergy, vol. 2015, no. 77, pp. 200-208, 2015. [http://dx.doi.org/10.1016/j.biombioe.2015.03.031]

[22] C.M. Drapcho, N.P. Nhuan, and T.H. Walker, Biofuels Engineering Process Technology., McGraw-Hill: New York, U.S.A, 2008. a

[23] C.M. Drapcho, N.P. Nhuan, and T.H. Walker, Biofuels Engineering Process Technology., McGraw-Hill: New York, U.S.A, 2008. b

[24] C. Karunanithy, K. Muthukumarappan, and J.L. Julson, "Influence of high shear bioreactor parameters on carbohydrate release from different biomasses", American Society of Agricultural and Biological Engineers Annual International Meeting, 2008 Rhode Island, U.K [http://dx.doi.org/10.13031/2013.24960]

[25] J. Lizasoain, F. Theuretzbacher, C. Lefever, R. Enguidanos, V. Werfring, A. Gronaeur, A. Bauer, and N. Weran, "Degradation Kinetics of Steam Exploded Wheat Straw During Anaerobic Digestion for Biogas Production", International Conference of Agricultural Engineering, 2014 Zurich, Germany

[26] J.V. Vermaas, L. Petridis, X. Qi, R. Schulz, B. Lindner, and J.C. Smith, "Mechanism of lignin inhibition of enzymatic biomass deconstruction", Biotechnol. Biofuels, vol. 8, p. 217, 2015. [http://dx.doi.org/10.1186/s13068-015-0379-8] [PMID: 26697106]

[27] G.L. Miller, "Use of Dinitrosalicylic Acid Reagent for Determination of Reducing Sugar", Anal. Chem., vol. 31, pp. 426-428, 1959. [http://dx.doi.org/10.1021/ac60147a030]

[28] A. Sluiter, B. Hames, R. Ruiz, C. Scarlata, J. Sluiter, D. Templeton, and D. Coker, Determination of Structural Carbohydrates and Lignin in Biomass., NREL: Colorado, U.S.A, 2008.

[29] N. Dussadee, R. Ramaraj, and T. Cheunbarn, "Biotechnological Applications of Sustainable Biogas Production through Dry Anaerobic Digestion of Napier Grass", Biotechnology (Faisalabad), vol. 2017, no. 7, p. 47, 2017.

[http://dx.doi.org/10.1007/s13205-017-0646-4]

[30] C.A. Cardona, O.J. Sanchez, and L.F. Gutierrez, Process Synthesis for Fuel Ethanol Production, CRC Press, Taylor \& Francis Group:: New York, U.S.A, 2010.

[31] V.S. Chang, and M.T. Holtzapple, "Fundamental factors affecting biomass enzymatic reactivity", Appl. Biochem. Biotechnol., vol. 84-86, pp. $5-37,2000$ [http://dx.doi.org/10.1385/ABAB:84-86:1-9:5] [PMID: 10849776]

[32] S. Kumar, Organic Chemistry: Spectroscopy of Organic Compounds., Department of Chemistry, Guru Nanak Dev University: Amritsar, 2006 .

(C) 2018 Samuel et al.

This is an open access article distributed under the terms of the Creative Commons Attribution 4.0 International Public License (CC-BY 4.0), a copy of which is available at: https://creativecommons.org/licenses/by/4.0/legalcode. This license permits unrestricted use, distribution, and reproduction in any medium, provided the original author and source are credited. 